\title{
Mesenchymal Stromal Cells from Different Parts of Umbilical Cord: Approach to Comparison \& Characteristics
}

\author{
Ekaterina Semenova ${ }^{1} \cdot$ Mariusz P Grudniak $^{1} \cdot$ Eugeniusz K Machaj $^{1} \cdot$ Katarzyna Bocian $^{1,2}$ • \\ Magdalena Chroscinska-Krawczyk ${ }^{3}$ - Marzena Trochonowicz ${ }^{1}$ - Igor M Stepaniec ${ }^{1}$ - Magdalena Murzyn ${ }^{1,4}$. \\ Karolina E Zagorska ${ }^{1}$ • Dariusz Boruczkowski ${ }^{1} \cdot$ Tomasz J Kolanowski $^{1,4} \cdot$ Tomasz Oldak $^{1}$ (D) Natalia Rozwadowska ${ }^{4}$
}

Accepted: 17 March 2021 / Published online: 15 April 2021

(C) The Author(s) 2021

\begin{abstract}
Mesenchymal stromal/stem cells (MSCs) are a unique population of cells that play an important role in the regeneration potential of the body. MSCs exhibit a characteristic phenotype and are capable of modulating the immune response. MSCs can be isolated from various tissues such as: bone marrow, adipose tissue, placenta, umbilical cord and others. The umbilical cord as a source of MSCs, has strong advantages, such as no-risk procedure of tissue retrieval after birth and easiness of the MSCs isolation. As the umbilical cord (UC) is a complex organ and we decided to evaluate, whether the cells derived from different regions of umbilical cord show similar or distinct properties. In this study we characterized and compared MSCs from three regions of the umbilical cord: Wharton's Jelly (WJ), the perivascular space (PRV) and the umbilical membrane (UCM). The analysis was carried out in terms of morphology, phenotype, immunomodulation potential and secretome. Based on the obtained results, we were able to conclude, that MSCs derived from distinct UC regions differ in their properties. According to our result WJ-MSCs have high and stabile proliferation potential and phenotype, when compare with other MSCs and can be treated as a preferable source of cells for medical application.
\end{abstract}

Keywords Mesenchymal stromal cells (MSCs) · Umbilical cord (UC) · Wharton's Jelly (WJ) · MSCs from perivascular region $(\mathrm{PRV}) \cdot \mathrm{MSC}$ from UC membrane $(\mathrm{UCM})$

Tomasz Oldak

Tomasz.Oldak@pbkm.pl

Ekaterina Semenova

katisemenovapr@gmail.com

Mariusz P Grudniak

Mariusz.Grudniak@pbkm.pl

Eugeniusz K Machaj

Krzysztof.Machaj@pbkm.pl

Katarzyna Bocian

Katarzyna.Bocian@pbkm.pl

Magdalena Chroscinska-Krawczyk

madziachr@wp.pl

Marzena Trochonowicz

Marzena.Trochonowicz@pbkm.pl

Igor M Stepaniec

Igor.Stepaniec@pbkm.pl

Magdalena Murzyn

Magdalena.Murzyn@pbkm.pl
Karolina E Zagorska

Karolina.Zagorska@pbkm.pl

Dariusz Boruczkowski

Karolina.Zagorska@pbkm.pl

Tomasz J Kolanowski

Tomasz.Kolanowski@pbkm.pl

Natalia Rozwadowska

natalia.rozwadowska@igcz.poznan.pl

Research and Development Department, Polish Stem Cell Bank, FamiCord Group, Ul. Jana Pawla II 29, 00-867 Warsaw, Poland

2 Faculty of Biology, Department of Immunology, University of Warsaw, Warsaw, Poland

Clinic of Paediatric Neurology, III Faculty of Paediatrics, Medical University of Lublin, Lublin, Poland

4 Institute of Human Genetics, Polish Academy of Sciences, Poznan, Poland 


\section{Introduction}

Mesenchymal stromal/stem cells (MSCs) can be isolated from different tissues or organs: bone marrow, adipose tissue, placenta, umbilical cord, amniotic fluid, liver, dental pulp, mobilized peripheral blood and others, but the most frequently used sources of MSCs remain bone marrow, adipose tissue. Unlike perinatal organs, adult tissues like bone marrow or adipose tissue have a number of limitations, such as: invasive acquisition procedure, higher risk of infectious diseases transmission, donor's age, and limited proliferative potential of MSCs [1-4].

Umbilical cord (UC) is a perinatal organ connecting placenta and fetus, so as to facilitate the exchange of nutrition and gases (oxygen and carbon dioxide). Cross-section of umbilical cord (Fig. 1) demonstrates, that UC is composed of various anatomical parts: amniotic membrane (UCM) - umbilical cord membrane, which contain two layers: epithelial and mesenchymal, perivascular region (PRV) surrounding and protecting blood vessels, and the central part of UC constituted by Wharton's Jelly (WJ) - a gelatinous substance rich in glycosaminoglycans, such as hyaluronic acid, chondroitin sulfate, which give that organ elasticity. Collection of UC is noninvasive and not associated with ethical issues, furthermore it is a good source to obtain considerable number of MSCs. These cells are characterized by a set of positive (CD73, CD90, CD105) and negative (CD45, CD14, CD34, CD19, HLA-DR) markers, adhesion to plastic surface and the capability of differentiation to other cell types, such as adipocytes, chondrocytes and osteoblasts $[5,6]$. The unique multipotency, immunomodulation capabilities with low or none immunogenicity, due to the low expression of HLA class II proteins define MSC's as potential source of therapeutic agents for regenerative medicine. The immunomodulatory features allow to use them in allo- and autogenic configuration $[7,8]$. Another important aspect of clinical use is the secretion of various growth factors and cytokines, such as G-CSF, HGF, PDGFAA, TGF- $\beta$, IL- 6 , IL- 8 and others, which play important roles not only in immunomodulation but also in promotion of cell proliferation, differentiation, growth and tissue repair [9-11].

Currently, MSCs are tested in more than 1000 clinical trials in plethora of diseases and conditions (Mesenchymal stromal/ stem cells search at www.clinicaltrials.gov). Use of autologous and allogeneic MSCs in study of cardiovascular diseases treatment was resulted in cardiac functions improvement, MSCs were well tolerated and no serious adverse effects were observed when infused intramyocardially/ transendocardially into patients [12-14]. MSCs application to treat multiple sclerosis resulted in enhancing myelin regeneration and secretion of various cytokines/chemokines/growth factors, such as superoxide dismutase-3 in experimental models and clinical applications [15-19]. Developing new strategies in neurodegenerative diseases like Parkinson's and Alzheimer's disease allowed to modulate inflammatory environment, increasing neuron survival by paracrine effect of MSCs thanks to their ability to secrete potentially neuroprotective factors: EGF, VEGF, NT3, FGF-2, HGF, BDNF [20-23] . Several ongoing clinical trials to treat bone and cartilage diseases are being conducted to determine the usefulness of MSCs, including ability to differentiate to chondrocytes and to secrete growth factors.
Fig. 1 Cross-section of fresh umbilical cord fragment, Masson staining. Showing the compartments from which cells have been isolated: UCM- the umbilical cord membrane (epithelial and mesenchymal layer), WJ- Wharton's jelly, PRV- the perivascular region, other abbrev.: A - arteries, V vein

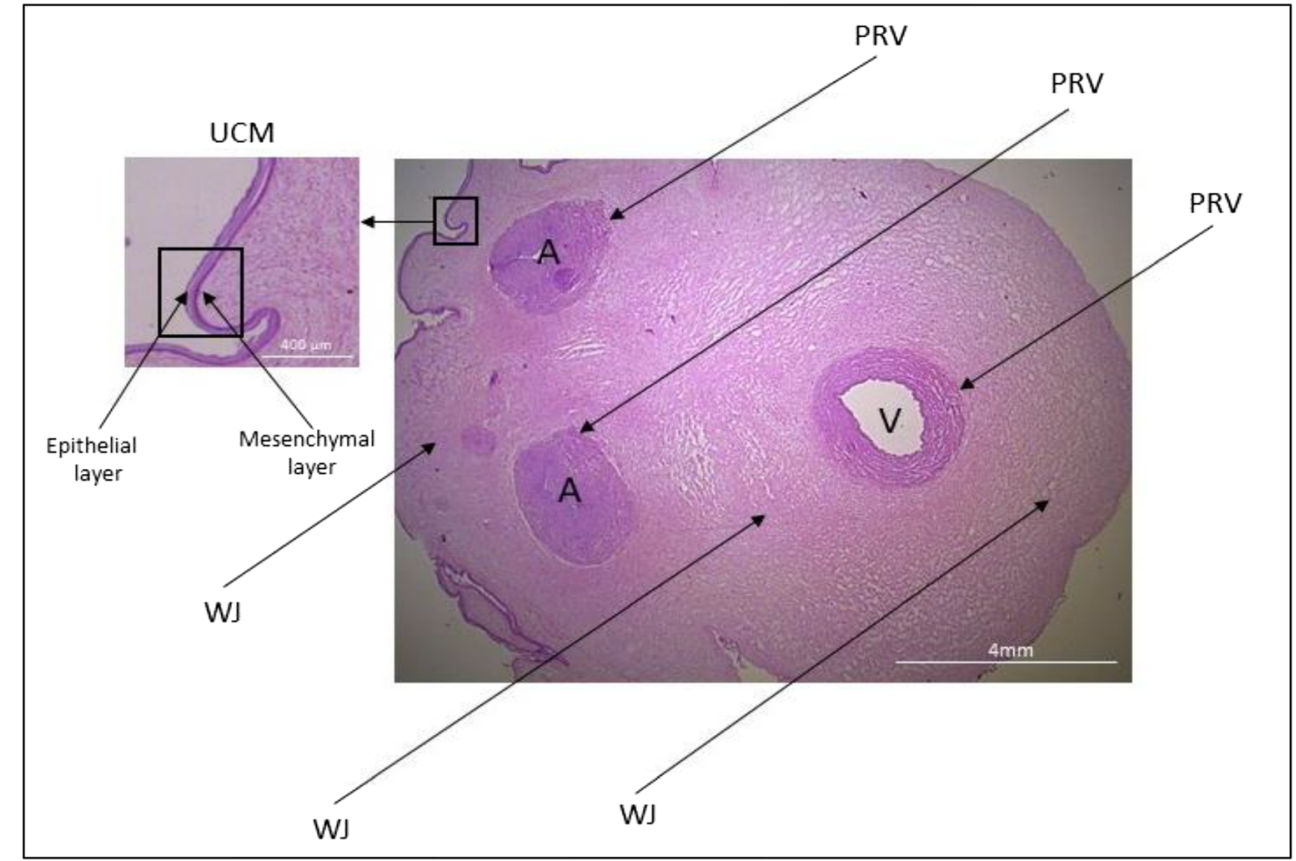


MSCs application in knee cartilage injury allowed to repair cartilage defect in any knee compartment using WJ-MSCembedded scaffolds [24, 25].

Although, UC appears to be a relatively homogeneous tissue, there are reports, that the MSCs present in UC are different, depending on the region of isolation [26]. In 2005 Sarugaser's group defined cells from perivascular UC area as MSCs progenitors [27]. Troyer et al. demonstrated the unique capabilities of MSCs from WJ [28], while Kita et al. isolated and characterized cells from umbilical cord membrane [29]. Nevertheless, the complex study, including the comparison of different regions from each UC in terms of gene and cytokine profiles have not been performed. The aim of our study was to deepen our knowledge about cells derived from three regions of UC: WJ, PRV and UCM. The study compared morphology, phenotypic profile, proliferation capabilities, differentiation possibilities, gene expression, cytokine profiles and senescence of MSCs isolated from three distinct UC regions.

\section{Materials and Methods}

\section{Materials Collection}

The umbilical cord $(\mathrm{UC}=10)$ were collected by trained midwifes after caesarean sections as well as natural deliveries after mother's informed consent, upon Ministry of Health approval. UC were washed in sterile $0,9 \% \mathrm{NaCl}$ (FRESENIUS $\mathrm{SE} \& \mathrm{CO}, \mathrm{KGaA}$, Germany) and transported to the lab at $4{ }^{\circ} \mathrm{C}$. After qualification the cords were processed $24 \mathrm{~h}$ after birth.

\section{Isolation and Expansion of MSCs}

The cells were isolated from three different parts of umbilical cord (i) Wharton's Jelly, (ii) perivascular region, and (iii) umbilical cord membrane region as it was shown in Fig. 1.

MSCs were isolated mechanically as described previously [8]. The main procedures were as follows: each part was gently separated and washed with sterile saline $(0.9 \%$ solution of $\mathrm{NaCl}$; FRESENIUS SE\&CO. KGaA, Germany) supplemented with antibiotics/antimycotic solution, which contain 10,000 units/mL of penicillin, $10,000 \mu \mathrm{g} / \mathrm{mL}$ of streptomycin, and $25 \mu \mathrm{g} / \mathrm{mL}$ of Gibco Amphotericin B, as recommended for use at $10 \mathrm{~mL} / \mathrm{L}$ (Antibiotic-Antimycotic (100x) catalog no. 15240096, Thermo Fisher Scientific, USA). Samples from each part were cut into small fragments (explants as small as 2-3 $\mathrm{mm}^{3}$ ), then washed twice with sterile saline, placed into $25 \mathrm{~cm}^{2}$ flasks (Thermo Fisher Scientific, USA) in complete StemMACS (TM) MSC Expansion Medium XF (catalog no. 130-104-182 Miltenyi Biotec, Germany) supplemented with antibiotics/antimycotic solution, which contain 10,000 units/ $\mathrm{mL}$ of penicillin, $10,000 \mu \mathrm{g} / \mathrm{mL}$ of streptomycin, and $25 \mu \mathrm{g} /$
$\mathrm{mL}$ of Gibco Amphotericin B, as recommended for use in cell culture applications at $10 \mathrm{~mL} / 1 \mathrm{~L}$ (Antibiotic-Antimycotic (100x) catalog no. 15240096, Thermo Fisher Scientific, USA), followed by incubation in standard in vitro culture conditions $\left(37^{\circ} \mathrm{C}, 5 \% \mathrm{CO}_{2}\right)$. After 2 weeks of explants incubation, cells were collected and expanded in the conditions described above. Cells obtained from short-term (passage 3) and long-term in vitro culture (passage 8 ) were evaluated.

\section{Cell Proliferation Potential}

Population Doubling Time (PDT) analysis was performed for assessment the proliferative potential of MSCs from UC $(\mathrm{UC}=10)$. MSCs were seeded $\left(10,000\right.$ cells $\left./ \mathrm{cm}^{2}\right)$ onto a T25 flasks until 90\% confluence was reached. Adherent cells were detached with $0.25 \%$ Trypsin-EDTA (Thermo Fisher Scientific, USA), washed in PBS (Thermo Fisher Scientific, USA), centrifuged (300 x g, $10 \mathrm{~min}$.) and resuspended in StemMACS (TM) MSC Expansion Medium XF. They were counted and PDT calculated according to the following formula:

$P D T=\frac{C T \times \ln 2}{\ln \frac{N_{f}}{N_{i}}}$

where: PDT - Population Doubling Time, CT - Culture Time in days, $\mathrm{N}_{\mathrm{f}}$ - final Number of MSCs, $\mathrm{N}_{\mathrm{i}}$ - initial Number of MSCs [30].

\section{Immunophenotypic Analysis}

To evaluate the surface antigen profile flow cytometry analysis was performed (UC=10). Cells were incubated with phycoerythrin (PE)-conjugated monoclonal antibodies against human antigens: CD73 (catalog no. 550257, BD Pharmingen ${ }^{\mathrm{TM}}$, BD Bioscence USA), CD90 (catalog no. 561970, BD Pharmingen $^{\mathrm{TM}}$, BD Bioscence USA), CD105 (catalog no. 560839, BD Pharmingen ${ }^{\mathrm{TM}}$, BD Bioscence USA), CD200 (catalog no. 552475, BD Pharmingen ${ }^{\mathrm{TM}}$, BD Bioscence USA), and fluorescein isothiocyanate (FITC)-conjugated monoclonal antibodies (later referred as the Mix-Ab) against: HLA-DR (catalog no. 555811, BD Pharmingen ${ }^{\mathrm{TM}}$, BD Bioscence USA), CD34 (catalog no. 345801, BD Pharmingen $^{\mathrm{TM}}$, BD Bioscence USA), CD45 (catalog no. 345808, BD Pharmingen ${ }^{\mathrm{TM}}$, BD Bioscence USA), CD19 (catalog no. 345788, BD Pharmingen ${ }^{\mathrm{TM}}$, BD Bioscence USA), CD14 (catalog no. 345784, BD Pharmingen ${ }^{\mathrm{TM}}$, BD Bioscence USA) human antigens according to instruction manual. All antibodies including isotypic control were obtained from BD Bioscience, USA, IgG-PE (catalog no. 555749, BD Pharmingen ${ }^{\mathrm{TM}}$, BD Bioscence) and IgG-FITC (catalog no. 345815, BD Pharmingen ${ }^{\mathrm{TM}}$, BD Bioscence USA). Cells 
from passages 3 and 8 were selected as the data evaluation points. The cells were specifically analyzed by selective gating Fig. 2. The samples were analyzed with the FACS Calibur cytometer (BD Bioscience, USA) and CellQuest software (BD Bioscience, USA).

\section{Cell Viability}

Viability of cells from passage 3 and passage $8(U C=10)$ were evaluated using the Accustain Solution, (Propidium Iodide - based) kit and ADAM-MC cell counter (Digital Bio, South Korea) according to the manufacturer's protocol.

\section{Differentiation Assay}

To evaluate MSCs differentiation potential, cells from the passage $3(\mathrm{UC}=3)$ were used, according to the procedure described previously $[7,27,31,32]$. In accordance with the recommendation, cells were seeded in density $5 \times 10^{3} / \mathrm{cm}^{2}$ onto 24-wells plates (Corning, USA). Adipo-, osteo- and chondrogenic differentiation was initiated by StemPro
Adipo-, Osteo- and Chondrogenesis Differentiation Medium (Thermo Fisher Scientific, USA), respectively. The culturing conditions were $37^{\circ} \mathrm{C}, 5 \% \mathrm{CO}_{2}$ in the air, and $90 \%$ of humidity. The medium was changed every $2-3$ days. After 3 weeks, the culture media were removed and the cultured cells were fixed with $4 \%$ Formaldehyde solution (Sigma, USA). The fixed cells were washed with phosphate-buffered saline (PBS). Oil Red O (Sigma, USA) staining was used to evaluate the adipogenic potential. Cells differentiated into osteoblast were stained with Alizarin Red (Sigma, USA) to assess calcium deposits. In order to assess chondrogenesis, the cells were stained with Alcian Blue (Sigma, USA). All stained cells were analyzed with a Leica DM IL light microscope (Leica, Germany).

\section{Gene Expression Analyses}

Purifying of total RNA extract from cells collected on P3 and P8 $(\mathrm{UC}=3)$ was performed with RNeasy Plus Mini kit (Qiagen, Germany). Total RNA was treated with RNAsefree DNAse I kit (Qiagen, Germany). Reverse transcription
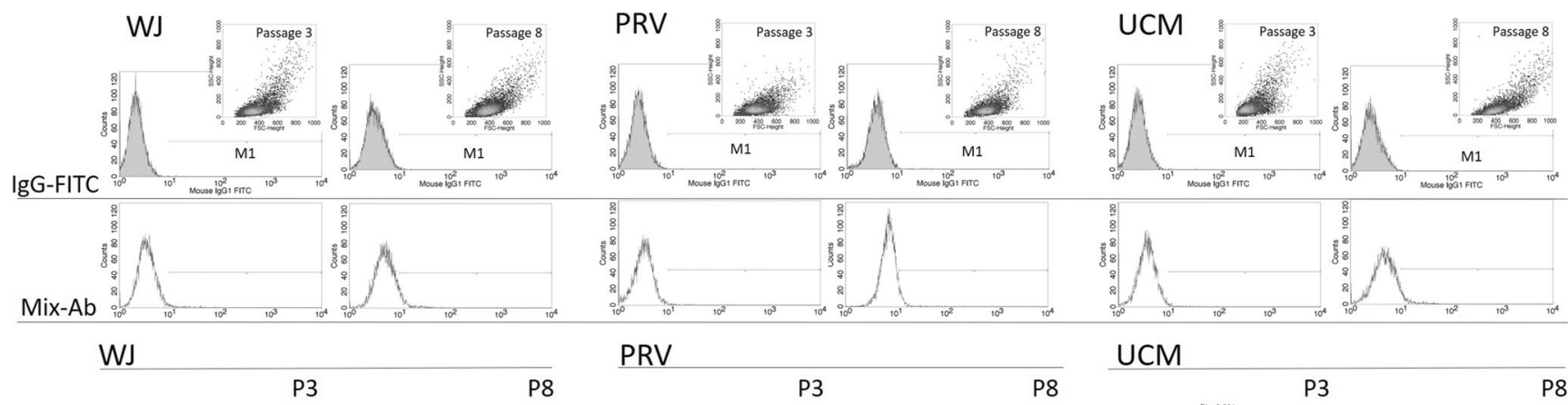

\section{PRV}
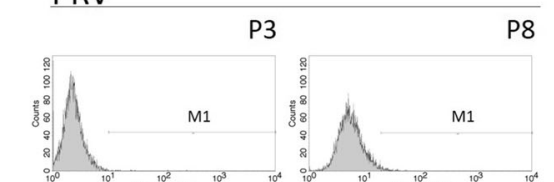

UCM
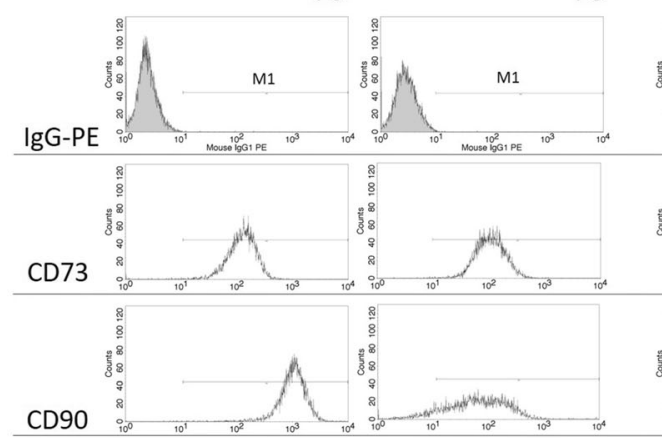

$\mathrm{CD90}$
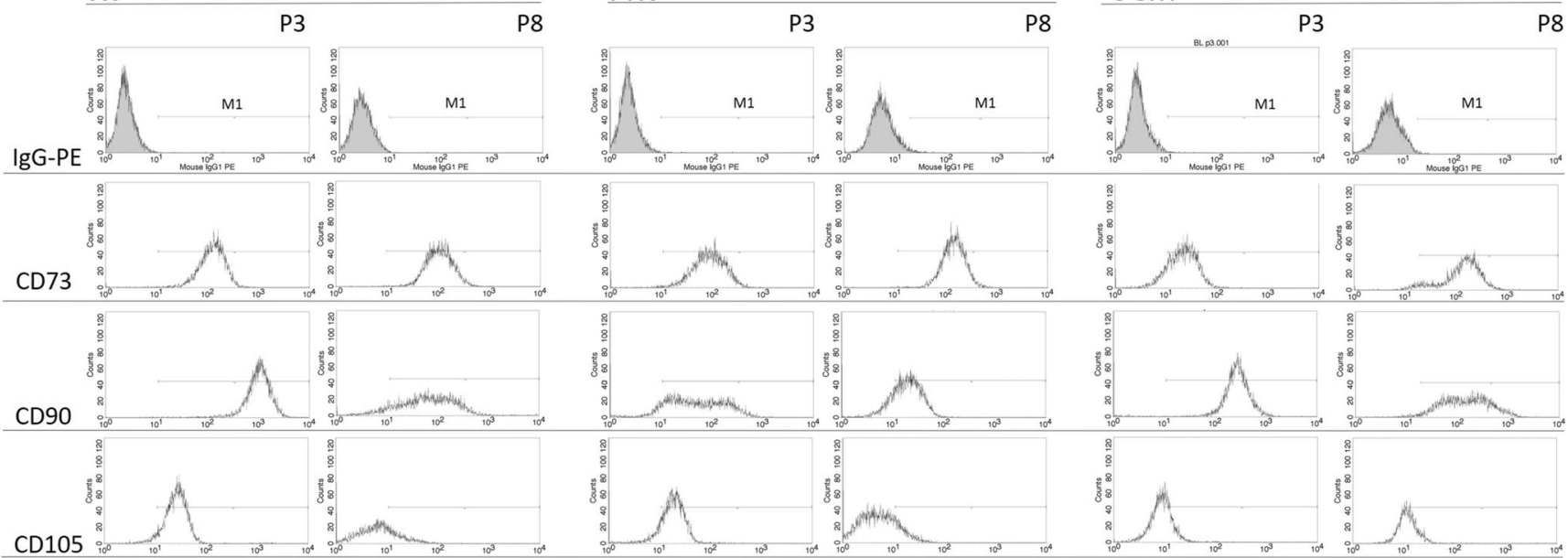

P8
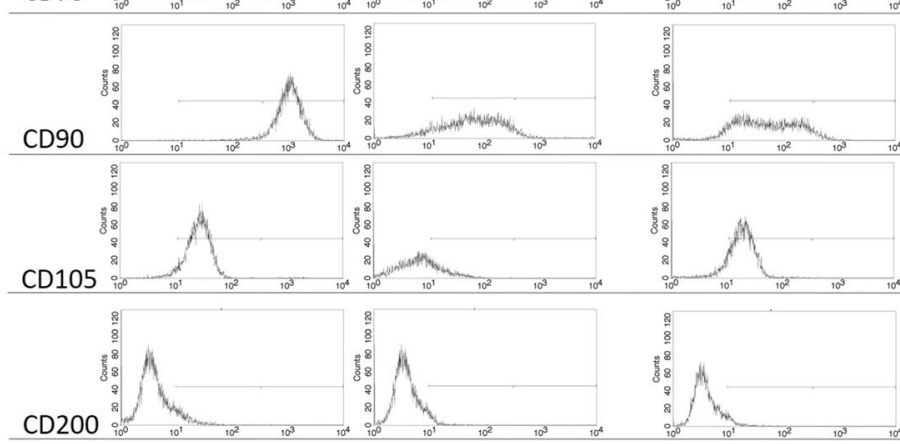

Fig. 2 Representative flow cytometry result showing the expression of CD73, CD90, CD105, CD200 as well as the lack or minimal expression of Mix-Ab (CD14, CD19, CD34, CD45, HLA-DR) on the MSC derived from Wharton Jelly (WJ), perivascular region (PRV) and umbilical cord membrane (UCM). The expression of selected markers have been

analyzed on cells shown on FSC/SSC dot plots. The gray histograms show the control labeling of cells with isotype antibodies: IgG-FITC, IgG-PE and the M1 area has been determined for positive cells (i.e. cells with expression of the observed markers) 
was performed on using RevertAid First Strand cDNA Synthesis Kit (Thermo Fisher Scientific, USA). $500 \mathrm{ng}$ of total RNA was used in this step. After reverse transcription, all cDNA samples were stored at $-80^{\circ} \mathrm{C}$ before analysis. qRTPCR for the expression of genes: RUNX, BGLAP, ADIPOQ, $F A B P 4, C O L 10 A 1, C O L 2 A 1$ and $C-M Y C$ was performed using SYBR Green Master Mix (Thermo Fisher Scientific). The primers used in our experiments were designed using NCBI primer BLAST and validated in silico with NETPrimer software. Designed primers were delivered by Genomed S.A. (Warsaw, Poland) (Table 1). Reactions were carried out in triplicate in a CFX $96+$ C1000 cycler (Bio-rad, USA). PCR reaction was used under the following conditions: activation at $95^{\circ} \mathrm{C}$ for $2 \mathrm{~min}$., denaturation at $95^{\circ} \mathrm{C}$ for $5 \mathrm{~s}$., annealing at $60{ }^{\circ} \mathrm{C}$ for $30 \mathrm{~s}$. for a total of 40 cycles. Immediately after last cycle, melting curve program were induced to ensure that only single, specific amplicons were produced. The results were analyzed according to the $2^{-\Delta \mathrm{Ct}}$ and normalized to GAPDH and HPRT 1 using CFX Maestro ${ }^{\mathrm{TM}}$ Software 1.1 (Bio-rad, USA).

\section{Secretome Analysis}

The culture media were collected from MSCs $(\mathrm{UC}=3)$ at passages 3 and 8 , centrifuged for $10 \mathrm{~min}$. at $10000 \mathrm{x} \mathrm{g}$ and supernatant was stored at $-80^{\circ} \mathrm{C}$ for the detection of proteins. A commercial magnetic bead panel kit (MILLIPLEX
HCYTOMAG-60 K and MILLIPLEX MAP TGF- $\beta 1,2,3$; Merck KGaA, Germany) was used for quantitative analysis of following chemokines (IL- 8, MCP-1, MIP- $1 \beta$, MIP- $1 \alpha$, RANTES, IP-10, Fractalkine), growth factors (TGF- $\beta 1$, TGF- $\beta 2$, TGF- $\beta 3$, G-CSF, GM-CSF, EGF, PDGF AA, FGF2, Flt-3 L), pro-inflammatory cytokines (IFN- $\gamma$, IL-2, IL-1 $\beta$, TNF- $\alpha$, IL-3, IL-12, IL-17) and anti-inflammatory cytokines (IL-4, IL-5, IL-6, IL-10, IL-13, IFN- $\alpha$ ). Sampling, processing and reagents preparation was performed according to the manufacturer's protocol. Analysis was performed by Magpix instrument and with Belysa 1.0.19 software (both by Merck KGaA, Germany).

\section{Senescence-Associated $\beta$-Galactosidase Assay}

To assess the activity of $\beta$-Galactosidase, the X-gal staining method was used. MSCs $(\mathrm{UC}=3)$ derived from three different parts of UC (WJ, PRV, UCM) harvested at passage 3 and 8 were seeded into 6-well plates (BD Biosciences, USA) with a density of 10,000 cells/well and cultured in standard conditions until sub-confluent cultures displaying comparable cell density $30-40 \%$. The cells were fixed with X-gal Fix buffer (0.1 M phosphate buffer ( $\mathrm{pH} 7.3$ ) supplemented with $5 \mathrm{mM}$ EGTA (pH 7.3), $2 \mathrm{mM} \mathrm{MgCl} 2$ and $0.2 \%$ glutareldahyde) (Sigma, USA) at room temperature for $15 \mathrm{~min}$. Then cells were washed with Wash buffer for X-gal staining $(0.1 \mathrm{M}$, $\mathrm{pH} 7.3$ phosphate buffer supplemented with $2 \mathrm{mM} \mathrm{MgCl}_{2}$ ),
Table 1 Primers used for evaluation of differentiation genes activation

\begin{tabular}{|c|c|c|c|}
\hline & Target gen & Primer & Sequence $\left(5^{\prime} \rightarrow 3^{\prime}\right)$ \\
\hline \multirow[t]{4}{*}{ Osteogenesis } & \multirow[t]{2}{*}{$R U N X$} & $\mathrm{~F}$ & ACGGGGCACTGGGCTT \\
\hline & & $\mathrm{R}$ & GTGAGGGATGAAATGCTTGGG \\
\hline & \multirow[t]{2}{*}{$B G L A P$} & $\mathrm{~F}$ & CCTCACACTCCTCGCCCTAT \\
\hline & & $\mathrm{R}$ & CTCTTCACTACCTCGCTGCC \\
\hline \multirow[t]{4}{*}{ Adipogenesis } & \multirow[t]{2}{*}{ ADIPOQ } & $\mathrm{F}$ & GCAGTCTGTGGTTCTGATTCC \\
\hline & & $\mathrm{R}$ & CCCTTGAGTCGTGGTTTCCT \\
\hline & \multirow[t]{2}{*}{ FABP4 } & $\mathrm{F}$ & GAAAGGCGTCACTTCCACGA \\
\hline & & $\mathrm{R}$ & ATGCGAACTTCAGTCCAGGTC \\
\hline \multirow[t]{4}{*}{ Chondrogenesis } & \multirow[t]{2}{*}{ COL10A1 } & $\mathrm{F}$ & GCTGAACGATACCAAATGCCC \\
\hline & & $\mathrm{R}$ & CCTTGCTCTCCTCTTACTGCT \\
\hline & \multirow[t]{2}{*}{ COL2A1 } & $\mathrm{F}$ & TGGTGCTGCTGACGCT \\
\hline & & $\mathrm{R}$ & CTGTCCCTTTGGTCCTGGTT \\
\hline \multirow[t]{4}{*}{ Pluripotency genes } & \multirow[t]{2}{*}{$S O X-2$} & $\mathrm{~F}$ & CGGAAAACCAAGACGCTCA \\
\hline & & $\mathrm{R}$ & GACCCCGCTCGCCAT \\
\hline & \multirow[t]{2}{*}{$C-M Y C$} & $\mathrm{~F}$ & CGCCTTCTCTCCGTCCTC \\
\hline & & $\mathrm{R}$ & $\begin{array}{l}\text { TCTTCСТCATCTTCTTGTTC } \\
\text { СТСС }\end{array}$ \\
\hline \multirow[t]{4}{*}{ reference genes } & \multirow[t]{2}{*}{$G A P D H$} & $\mathrm{~F}$ & TGAAGGTCGGAGTCAACGG \\
\hline & & $\mathrm{R}$ & CTGGAAGATGGTGATGGGATTT \\
\hline & \multirow[t]{2}{*}{$H P R T 1$} & $\mathrm{~F}$ & CTGGCGTCGTGATTAGTGATGA \\
\hline & & $\mathrm{R}$ & GAGGGCTACAATGTGATGGC \\
\hline
\end{tabular}


followed by the X-gal staining buffer addition and overnight cells incubation at $37^{\circ} \mathrm{C}$. Cells were washed with Wash buffer again and examined for the blue color presence with Leica DM IL LED microscope and images were captured with a connected digital camera (Leica, Germany) and analyzed with LAS V4.12 (Leica, Germany) software.

\section{Statistical Methods}

Data were analyzed with Statistica software (StatSoft Polska). Statistical data are presented as means \pm standard deviation for at least three replicates. Comparisons inside particular groups as well as between groups were done using ANOVA with significance set at a $p$ value of less than 0.05 .

\section{Results}

\section{Isolation, Expansion and PDT Analysis of Cells}

MSCs were effectively isolated according to explants method described above from all three parts: Wharton Jelly (WJ), perivascular region (PRV) and umbilical cord membrane (UCM). The cells from all groups grew attached to plastic dishes and showed the characteristic MSC fibroblast-like shape (Fig. 3). The investigated MSCs demonstrated no significant differences in morphology.

The cells obtained from WJ, PRV, UCM showed similar growth characteristic from passages $\mathrm{P} 1$ to $\mathrm{P} 8$ and demonstrated congruous proliferation potential without statistically significant differences (Fig. 4). The mean PDT for all investigated lines was: WJ $1.35 \pm 0.15$, PRV $1.16 \pm 0.12$; UCM $1.47 \pm 0.15$. After passage 12 the cell division rates slowed in all types of tested cells. While cells from WJ and PRV during P12-P13 behaved similarly and maintained PDT within 2-4 days, the cells obtained from UCM demonstrated a rapid increase of PDT after passage 12 , and subsequently lost the ability to proliferate at passage 13. The PRV showed consistent increase in PDT and the PRV cultures had to be terminated at passage 14. In the case of WJ cells, the period of PDT plateau was longer (P1-P14), with observed increase of PDT was after passage 14 . WJ cells kept the proliferation capacity till the passage 17 .

\section{Immunophenotypic Analysis}

All investigated cell populations derived from WJ, PRV and UCM from passage 3 and 8 included cells positive for CD73, CD90, CD105 and negative for HLA-DR, CD34, CD45, CD 19, CD14. In the case of negative marker cocktail, no significant differences were observed. However, cells from WJ and UCM from passage 3 showed significant differences in the percentages of CD73 positive cells $(97.8 \pm 1.3 \%$ and $70.8 \pm 5.8 \%$ for WJ and UCM, respectively) (Fig. 5). The percentages of CD105 positive cells were significantly higher in cells isolated from $\mathrm{WJ}$ region in comparison to PRV and $\mathrm{UCM}(93.7 \pm 1.3 \% ; 69.7 \pm 2.6 \% ; 32.4 \pm 9.8 \%$ for $\mathrm{WJ}$, PRV, UCM, respectively). In the case of CD90, the percentage of positive CD90 cells at passage 3 was higher in WJ compared to PRV and UCM $(99.3 \pm 0.3 \%$; $93.8 \pm$ $0.2 \% ; 97.6 \pm 0.2 \%$ for $\mathrm{WJ}, \mathrm{PRV}, \mathrm{UCM}$, respectively).

At the passage 8, the cells from all parts of UC showed decreased percentage of $\mathrm{CD} 73^{+} \mathrm{CD} 90^{+} \mathrm{CD} 105^{+}$cells, when compared to the cells assessed at passage 3 . The exception were the cells from UCM region, where the percentage of $\mathrm{CD} 73$ positive cells increased by $7 \%$ in comparison to passage 3. Cells from P8 demonstrate lower percentage of CD73 positive cells in comparison to $\mathrm{P} 3$ but without statistically significant differences between regions $(75.2 \pm 1.8 \% ; 66.5 \pm 2.9 \% ; 75.8 \pm 8.9 \%$ for $\mathrm{WJ}$, PRV, UCM, respectively). In the case of the CD90 marker, the percentage of CD90 positive cells from WJ was higher than those from PRV region $(69 \pm 0.7 \% ; 52.7 \pm$ $6 \% ; 64.8 \pm 3.3 \%$ for WJ, PRV, UCM, respectively). The percentage of CD105 positive cells was significantly higher in WJ $(33.5 \pm 9.1 \%)$ cells to compare with UCM $(21.2 \pm 2.5 \%)$ and PRV $(24.1 \pm 1.4 \%)$.
Fig. 3 Representative

morphology of cells derived from distinct umbilical cord regions: Wharton's Jelly (WJ), the perivascular space (PRV) and the umbilical membrane (UCM). Cells grown as a typical spindleshaped cells and formed a monolayer of adherent cells after of culture in StemMACS (TM) MSC Expansion Medium XF

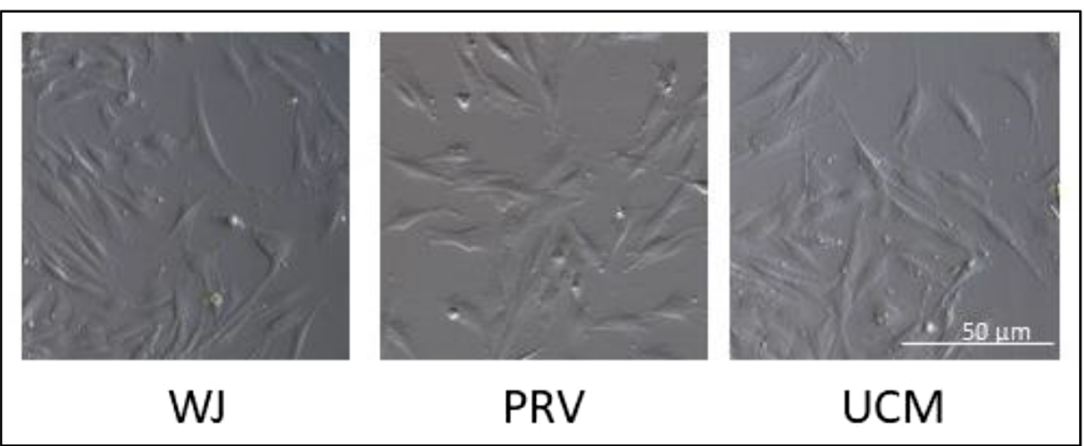


Fig. 4 Growth kinetics of cells isolated from Wharton Jelly (WJ), perivascular region (PRV) and umbilical cord membrane (UCM) were evaluated using PDT (Population Doubling Time) analysis. Cultures were observed from passages $1,3,5,8,12-17$. The horizontal lines above the graph indicate statistically significant differences between passages of the same compartment of umbilical cord $(* p<0,05)$

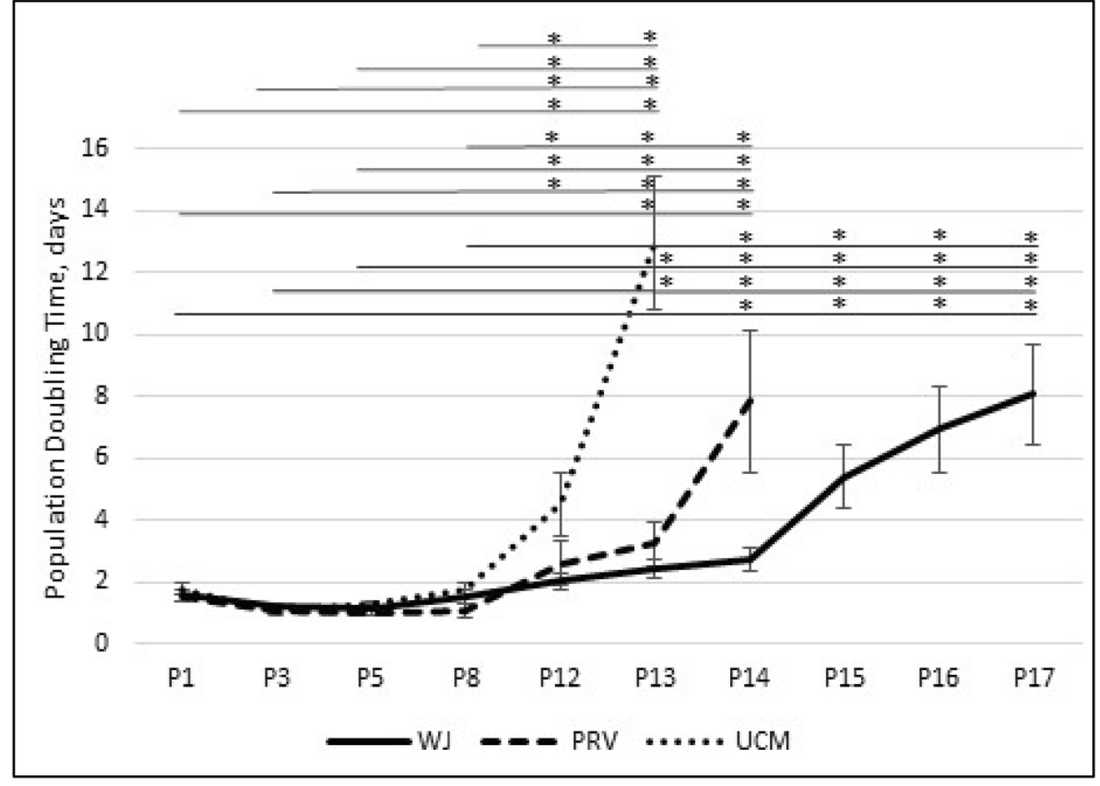

The highest percentage of CD200 positive cells was found in cells from $\mathrm{WJ}$ in passage $3(21 \%)$, then the percentage of $\mathrm{CD} 200^{+}$cells significantly decreased nearly to zero $(0.2 \%)$ at the passage 8 (Fig. 6). On the other hand, $\mathrm{CD}^{2} 00^{+}$cells in PRV and UCM populations remain stable, yet very low population subsets at both P3 and P8 (about 0.6\%).
Fig. 5 FACS analysis of characteristic phenotype of MSC cells derived from Wharton Jelly (WJ), the perivascular region (PRV) and the umbilical cord membrane (UCM). The expression of CD73, CD90, CD105 were identified on the MSCs with the lack or minimal expression of CD14, CD19, CD34, CD45, HLA-DR. The horizontal lines above the graph indicate statistically significant differences between cells from different parts of umbilical cord from passage 3 and 8 . The flow cytometry analysis of the surface antigen profile was performed from 10 umbilical cords. $(* p<0,05)$
Passage 3

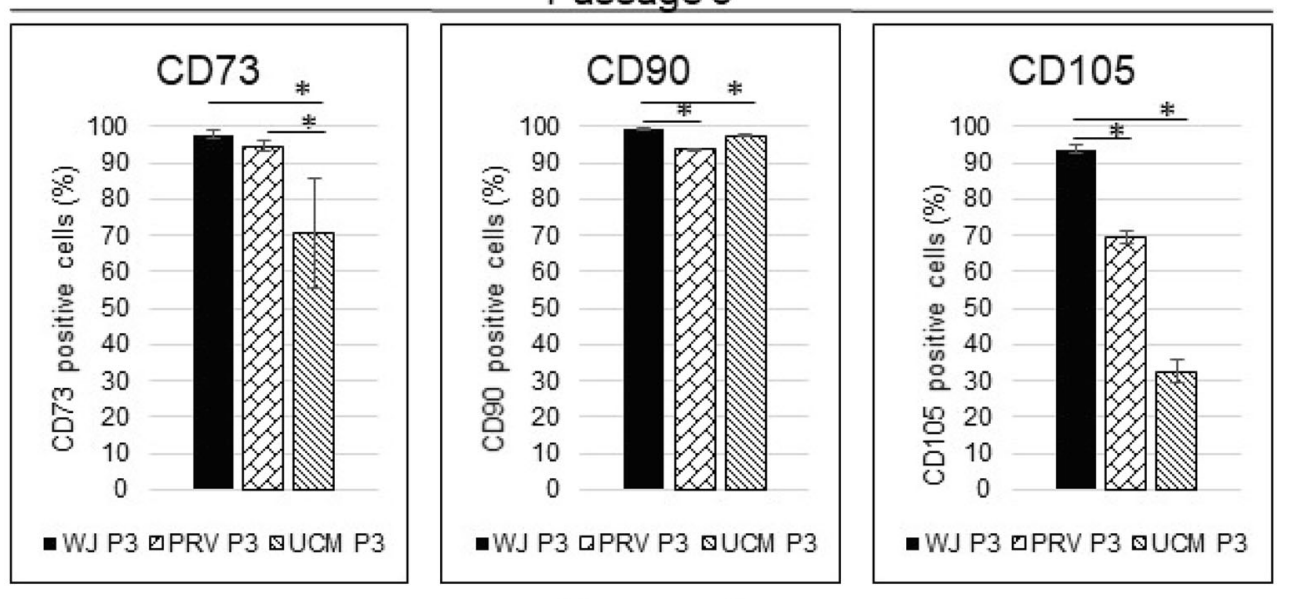

Passage 8

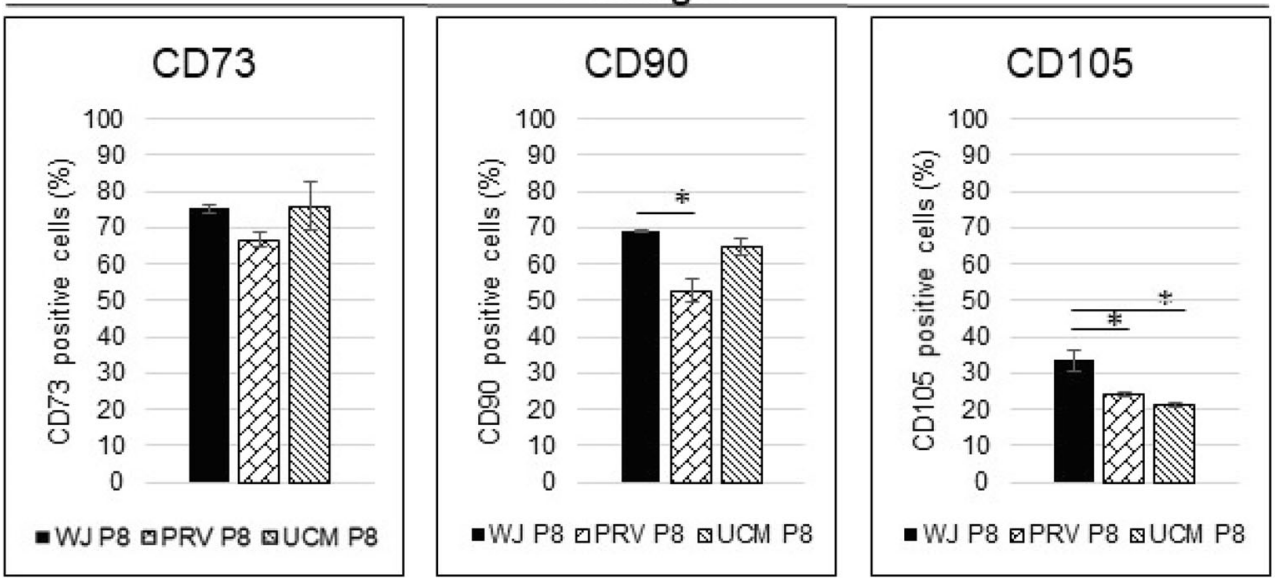




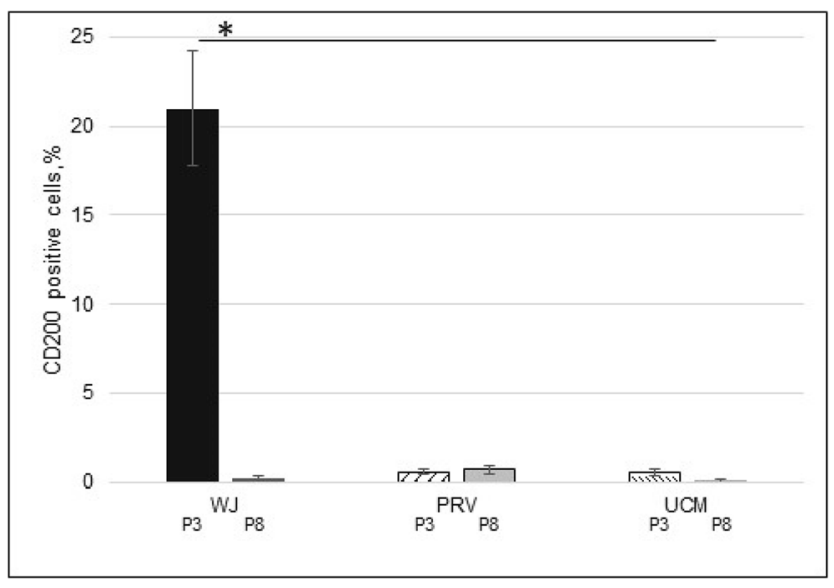

Fig. 6 The flow cytometry analysis of CD200 expression in the cells from different regions: from Wharton jelly (WJ), perivascular region (PRV) and umbilical cord membrane (UCM) from passage 3 and 8. The horizontal line above the graph indicates statistically significant differences between WJ cells from passage 3 and the rest of MSCs. The flow cytometry analysis was performed from 10 umbilical cords $\left({ }^{*} \mathrm{p}<\right.$ $0,05)$

\section{Cell Viability}

Cells from investigated regions of UC demonstrated high viability, not less than $86 \%$, even in those from passage 8 (data not shown). The highest percentage (97\%) of viable cells was found in WJ cells from passage 3. A similar percentage of viable cells was found in all groups of cells from passage 8 . Overall, there was a downward trend in the percentage of live cells throughout the culture period.

\section{In Vitro Differentiation}

Cells from WJ, PRV, UCM differentiated in adipocyte, osteocyte and chondrocyte lines (Fig. 7). Such type of differentiation test allowed only for qualitative assessment, however, the intensity of staining was evaluated globally, based on acquired images. Adipocyte colonies stained with Oil Red O were different in numbers: more stained colonies were observed in cells from WJ and PRV regions. In the case of osteocyte differentiation, cells from WJ region showed the highest intensity and number of staining substances. MSCs from the WJ and PRV treated with chondrocyte differentiation medium showed a higher number of stained cells than those from UCM.

\section{Gene Expression Results}

The expression of differentiation-related genes (osteogenic $R U N X, B G L A P$; adipogenic FABP4, ADIPOQ; chondrogenic $C O L 2 A 1, C O L 10 A 1)$ and $C-M Y C$ was studied in order to analyze the differences in gene expression between MSCs from three different parts of umbilical cord (Fig. 8). C-MYC was expressed in all MSCs lines, the cells from WJ, PRV and
UCM from passage 3 showed comparable level of mRNA expression. The highest level of $C-M Y C$ expression was shown by WJ-MSCs at passage 8 . In general, an increase of $C-M Y C$ expression was observed from passages 3 to 8 .

$F A B P 4$ expression was observed in all studied cells, but the highest level was detected in the UCM cells. In the other cells FABP4 expression level was very low. Interestingly, in all cells from passage 3 , a tendency to greater expression was observed in comparison to the cells from passage 8 .

Cells derived from short-term cultivation (P3) showed a comparatively low expression of terminal chondrocyte differentiation markers type X collagen (COL10A1). However, in the case of the cells from PRV and UCM, the expression of COL10A1 increased 2-3 folds during the cultivation from passages 3 to 8 . The typical adipocyte gene $A D I P O Q$ and chondrocyte gene COL2A1 expression was not detected in any MSCs. All cells expressed mRNA considered as osteogenic markers, such as $R U N X, B G L A P$. In the case of $R U N X$ gene the highest expression was observed in PRV cells. Cells from $\mathrm{WJ}$ and $\mathrm{UCM}$ expressed $R U N X$ at a comparable level and this parameter was stable during culture till P8. BGLAP was expressed by studied cells from all investigated parts of the umbilical cord. Increased $B G L A P$ expression from P8 cells was observed in all cell groups. The highest level of $B G L A P$ expression was observed in PRV cells in comparison to other studied groups.

\section{Secretome Analysis}

MSCs secrete a wide range of growth factors, cytokines and chemokines. We have identified the presence of proteins, such as IL-1 $\beta$, IL-6, IL-8, IL-13, MCP-1, EGF, Fractalkine, Flt3 L, G-CSF, IFN $\alpha$, IP- 1 , TGF- $\beta 1$, TGF- $\beta 2$, TNF $\alpha$, PDGF AA (Table 2). The highest concentration of cytokines/ chemokines for P3 cells concerned IL-6, TGF- $\beta 1$, IL-8 and MCP-1. The statistically significant highest level of IL-6 level was observed in WJ-MSCs to compared with PRV- and UCM-derived $(1070 \pm 177.1,539.8 \pm 82.5,612.3 \pm 189 \mathrm{pg} /$ $\mathrm{ml}$, respectively) cells from passage 3 . However, only cells from WJ showed stable level of IL-6 during in vitro culture. For PRV and UCM cells 3 times increased secretion of IL-6 in passage 8 was noticed (in the case of UCM cells and the difference in IL- 6 level between passages 3 and 8 was statistically significant). TGF- $\beta 1$ levels were comparable and constant in all types of P3 and P8 cells. The MCP-1 level was stable during in vitro culture of all three MSC-subtypes, but in the case of UCM cells the MCP-1 level was 5 times higher than observed WJ and PRV. The stable level of TGF- $\beta 2$ was observed in PRV cells regardless of in vitro culture duration (139.2 pg/ml, $144.1 \mathrm{pg} / \mathrm{ml}$, respectively), while in the case of WJ- and UCM-derived cells an increase was noticed in passage 8 to compare with cells from passage 3 . In the case of cells from obtained from passage 3 , lower level of IP-10 was 


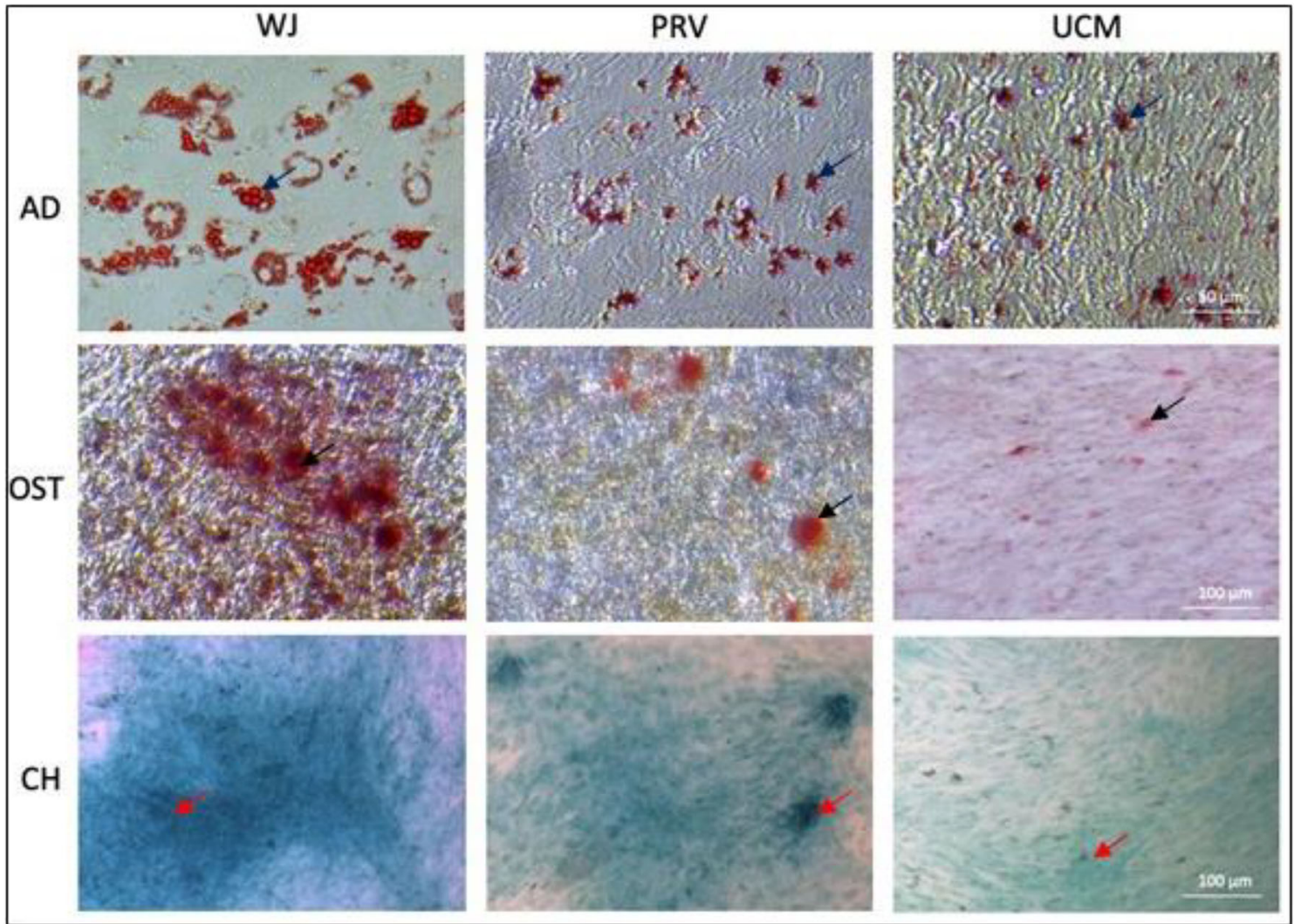

Fig. 7 MSCs from WJ, PRV, UCM differentiate in adipocyte, osteocyte and chondrocyte lines. Representative differentiation of cells from passage 3 from Wharton jelly (WJ), perivascular region (PRV) and umbilical cord membrane (UCM) into adipogenic (AD), osteogenic (OST) and chondrogenic $(\mathrm{CH})$ lineages. Adipogenic differentiation was examined by Oil Red staining, the differentiated culture demonstrates lipid vacuole formation typical for mature adipocytes (dark blue arrows) (scale bars, $50 \mu \mathrm{m}$ ); osteogenic differentiation was assessed by Alizarin Red staining of mineralized bone matrix (black arrows) (scale bars, $100 \mu \mathrm{m}$ ); chondrogenic differentiation was examined using Alcian Blue and blue color indicates cartilage extracellular matrix (red arrows) (scale bars, $100 \mu \mathrm{m})$

\section{Discussion}

The mesenchymal stromal cells from umbilical cord are a valuable tool for stem cell therapy and regenerative medicine $[7,27,31,32]$. MSCs can be effectively isolated from different parts of UC: the perivascular region (PRV) surrounding the vessels, UC lining (UCM) and Wharton Jelly (WJ) as it was previously described [32-37]. Our study is one of the first focused on comprehensive characteristics of MSCs derived from different regions of human umbilical cord including phenotype, senescence, proliferation potential, expression and secretory profile. The aim of our study was to characterize cell population isolated from specific UC region to identify potential differences and determine their usage in future regenerative or/and immunomodulatory therapies. We investigated the effects of prolonged in vitro expansion (as long as passage 8) on phenotypic, proliferative, secretory, senescence and functional features of UC-derived MSCs [34, 35]. We also analysed selected gene expression profile in aspect MSCs origin and time of in vitro cultivation.

Xu et al. compared MSCs from different part of UC: whole UC, umbilical vessels, Wharton's Jelly and amniotic 


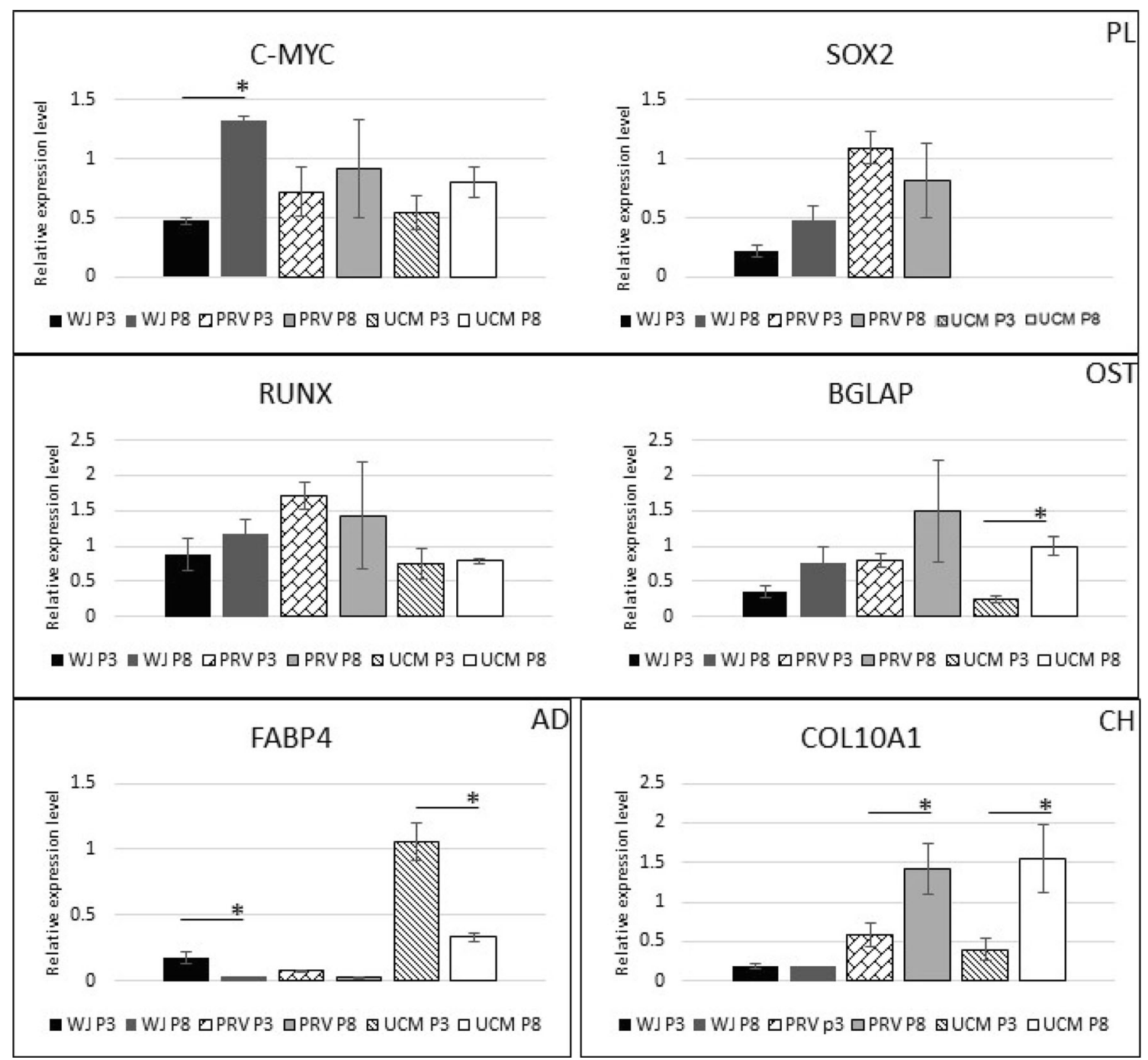

Fig. 8 Comparison of gene expression profiles of cells from passage 3 (P3) and 8 (P8) from Wharton jelly (WJ), perivascular region (PRV) and umbilical cord membrane (UCM). PL - mRNA expression of pluripotency related genes $C-M Y C, S O X 2$; OST - mRNA expression of

membrane [35]. Their results demonstrated that MSCs from investigated regions possessed similar biological characteristics and properties to differentiate into osteoblasts, adipo- and chondrocytes and inhibited the proliferation of allogeneic $\mathrm{T}$ lymphocytes. Lim and Phat isolated MSCs from cord lining and confirmed that these cells had MSCs characteristics and differentiation abilities [33] . Subramanian et al. reported that cells from whole UC, amnion, subamnion, perivascular and WJ were typical "MSCs", but, in fact, only MSCs from WJ characterized by high proliferation and differentiation potential and obtained populations were of higher purity than in other groups [36]. This data are with agreement with our findings that morphology and adherence properties are not different within all UC-derived MSCs population. We confirmed that cells isolated from different regions of UC grew attached to the plastic dish and in each case had fibroblast-like shape. osteoblast related genes: RUNX, BGLAP; AD - mRNA expression level of adipocyte related gene: $F A B P 4 ; \mathbf{C H}-$ mRNA expression level of chondrocyte related gene: COL10A1. $(* p<0,05)$

However, only cells obtained from WJ cells fulfilled all ISCT minimum MSC phenotype criteria [5]. In our hands the phenotypes of cells derived from PRV and UCM were distinct, especially in the case of UCM cells, which showed significantly lower level of $\mathrm{CD} 73^{+}$and $\mathrm{CD} 105^{+}$cells. Our experiments confirmed that the cells from different parts of UC varied from each other not only by minimal criteria, but by more subtle parameters, such as proliferation potential, immunomodulation and protein secretion ability. According to our research, the main advantages of WJ-MSCs were that they showed high proliferation potential up to passage 14, with no signs of aging until passage 8 and ability to culture up to passage 17. In comparison PRV- and UCM-derived cells, maintaining morphology and phenotype only until to passage 8 . We noticed a high percentage of CD200-positive cells from WJ analyzed on passages 3 in comparison to PRV 
Table 2 The secretome of MSCs from Wharton jelly (WJ), perivascular region (PRV) and umbilical cord membrane (UCM). Marked concentrations represent the statistically significant differences $(* p \leq 0,05)$ $v$. passage 3 . The rest of analyzed proteins concentrations remained unchanged without significant differences. The results of remaining analytes (FGF-2, GMCSF, IFN $\gamma$, IL-10, IL-12p40, IL17A, IL-2, IL-3, IL-4, IL-5, IL-7, MIP- $1 \alpha$, MIP- $1 \beta$, TGF- $\beta 3$ ) were at a very low level or outside the method resolution and were not used in this analysis

\begin{tabular}{|c|c|c|c|c|c|c|}
\hline \multirow[b]{2}{*}{$\begin{array}{l}\text { protein/ } \\
\text { (pg/ml) }\end{array}$} & \multicolumn{2}{|l|}{ WJ } & \multicolumn{2}{|l|}{ PRV } & \multicolumn{2}{|l|}{ UCM } \\
\hline & P3 & P8 & P3 & P8 & P3 & P8 \\
\hline IL-6 & $\begin{array}{c}1070.1 \pm \\
177.1\end{array}$ & $911.0 \pm 225.2$ & $539.8 \pm 82.5$ & $\begin{array}{r}1900.3 \pm \\
1439.1\end{array}$ & $\begin{array}{r}612.3 \pm \\
189.0\end{array}$ & $\begin{array}{r}1690.3 \pm \\
592.0^{*}\end{array}$ \\
\hline TGF- $\beta 1$ & $535.6 \pm 194.7$ & $398.0 \pm 65.0$ & $\begin{array}{r}809.7 \pm \\
151.4\end{array}$ & $606.5 \pm 153.7$ & $\begin{array}{r}529.6 \pm \\
172.4\end{array}$ & $607.5 \pm 151$ \\
\hline IL-8 & $367.0 \pm 44.1$ & $\begin{array}{c}785.7 \pm \\
170.1 *\end{array}$ & $134.0 \pm 25.9$ & $415.3 \pm 206.6^{*}$ & $\begin{array}{r}211.9 \pm \\
144.7\end{array}$ & $309.6 \pm 266.1$ \\
\hline MCP-1 & $121.8 \pm 58.4$ & $73.7 \pm 11.4$ & $93.9 \pm 19.5$ & $71.0 \pm 7.8$ & $\begin{array}{r}505.9 \pm \\
130.6\end{array}$ & $614.5 \pm 364.4$ \\
\hline TGF- $\beta 2$ & $68.9 \pm 20.8$ & $165.8 \pm 47.3^{*}$ & $139.2 \pm 77.0$ & $144.1 \pm 19.8$ & $67.2 \pm 15.6$ & $270.1 \pm 17.6^{*}$ \\
\hline IP-10 & $16.6 \pm 1.3$ & $26.5 \pm 3.7 *$ & $6.8 \pm 2.0$ & $24.6 \pm 4.2 *$ & $14.3 \pm 3.2$ & $38.1 \pm 12.0^{*}$ \\
\hline G-CSF & $14.9 \pm 5.3$ & $10.8 \pm 3.6$ & $29.4 \pm 4.8$ & $14.6 \pm 5.6$ & $13.9 \pm 5.1$ & $945.9 \pm 596^{*}$ \\
\hline PDGF AA & $11.1 \pm 2.6$ & $35.6 \pm 7.3 *$ & $56.6 \pm 4.7$ & $8.3 \pm 3.1 *$ & $7.7 \pm 1.9$ & $15.6 \pm 13.2$ \\
\hline Fractalkine & $27.2 \pm 5.3$ & $35.8 \pm 5$ & $22.0 \pm 7.4$ & $35.1 \pm 4.9$ & $20.5 \pm 10.8$ & $36.2 \pm 14.3$ \\
\hline IL-13 & $3.7 \pm 1.1$ & $3.4 \pm 0.4$ & $3.8 \pm 1.0$ & $3.3 \pm 0.3$ & $2.7 \pm 0.1$ & $3.9 \pm 1.0$ \\
\hline $\mathrm{IFN} \alpha$ & $8.4 \pm 1.5$ & $12.4 \pm 2.3$ & $9.4 \pm 0.8$ & $11.1 \pm 3.4$ & $10.3 \pm 1.0$ & $13.3 \pm 5.6$ \\
\hline Flt-3 L & $5.6 \pm 2.7$ & $5.9 \pm 2.2$ & $4.8 \pm 1.9$ & $5.7 \pm 3.4$ & $5.8 \pm 2.7$ & $9.7 \pm 4.0$ \\
\hline EGF & $4.4 \pm 0.6$ & $4.8 \pm 0.4$ & $4.2 \pm 0.6$ & $5.0 \pm 0.5$ & $4.0 \pm 0.0$ & $5.9 \pm 1.0$ \\
\hline $\mathrm{TNF} \alpha$ & $1.7 \pm 0.3$ & $1.4 \pm 0.0$ & $1.6 \pm 0.0$ & $1.6 \pm 0.1$ & $1.4 \pm 0.3$ & $1.8 \pm 0.4$ \\
\hline IL-1 $\beta$ & $1.3 \pm 0.1$ & $1.3 \pm 1.0$ & $0.8 \pm 0.2$ & $1.1 \pm 0.9$ & $1.2 \pm 0.0$ & $3.5 \pm 2.9$ \\
\hline
\end{tabular}

and UCM cells $[38,39]$. CD200 is involved in the immunoregulatory mechanism [40-43] and may provide a promising treatment strategy in neuroinflammatory diseases, like stroke, cerebral ischemia, Alzheimer's disease, Parkinson's disease, multiple sclerosis [44-49].

The presence of $C-M Y C$ expression in MSCs in all analyzed population also confirmed the fact that these cells possess a high proliferative capability [50]. Paula et al. demonstrated that growth factors from culturing media are able to increase expression of $C-M Y C$, which leads to improvement of proliferative ability of the cells [51]. It should be added that $C-M Y C$ takes part in other biological processes, such as cell differentiation and apoptosis [52]. The expression of $C-M Y C$ in MSCs is not related to malignant transformation [52-55],

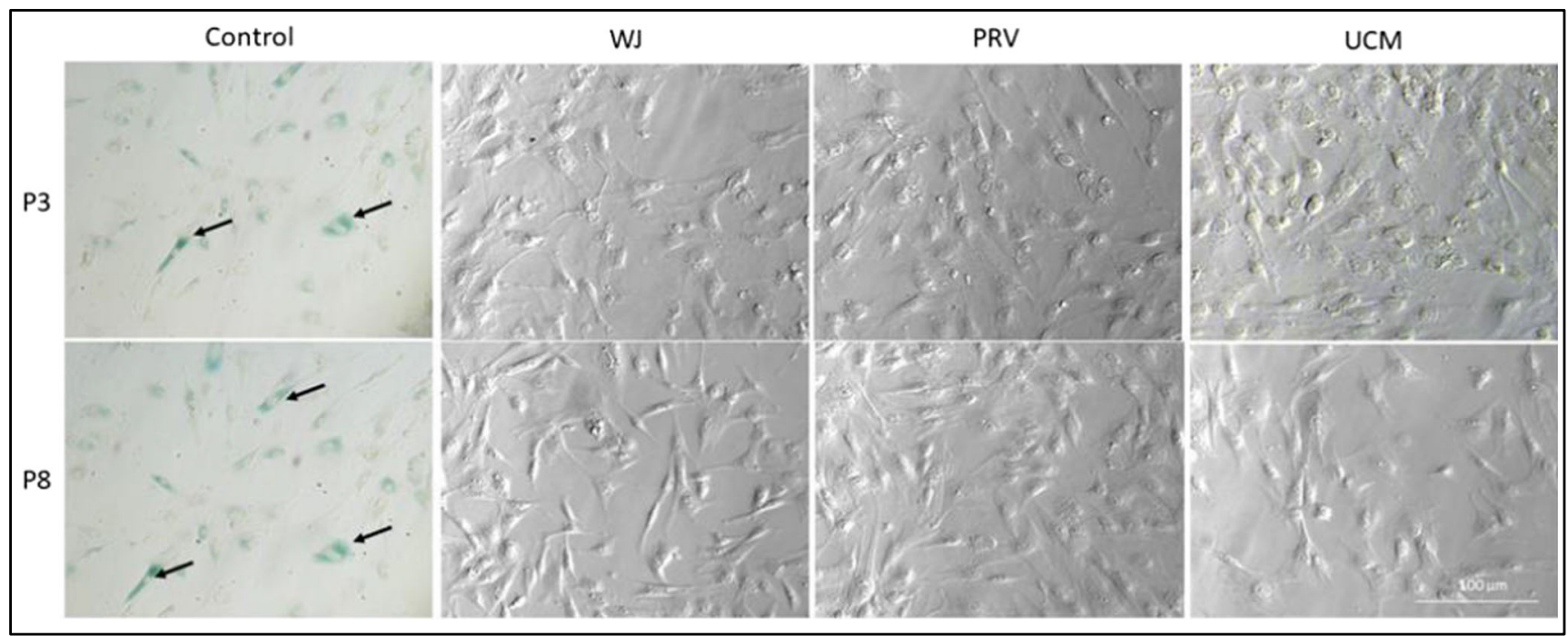

Fig. 9 Representative $\beta$-Gal analysis in MSCs at P3 and P8 passages. Cells were analyzed under a light microscope. SA- $\beta$-gal activity was not noted in MSCs until P8. The figure is representative of cells grown from one donor for each cell type Wharton jelly (WJ), perivascular region
(PRV) and umbilical cord membrane (UCM). As a control cells were used MSCs from UC isolated by standard method and treated by $\mathrm{H}_{2} \mathrm{O}_{2}$ to induce premature ageing representative blue cells, as markers of senescence, are indicated by black arrows 
and is present and indispensable in many other cell types. Melnik et al. confirmed that transplantation of generated MSCs with increased C-MYC expression did not result in tumor growth in any tissue in mice [55]. In fact, increased expression of $C-M Y C$ alone did not lead to MSCs transformation/malignant formation. Nair et al. confirmed that only the co-expression of $C-M Y C$ with HER2 (ERBB2) oncogene could result in increased risk of malignant transformation [53]. This finding was also confirmed by other scientific groups when $C-M Y C$ expression coexisted with loss/ silencing of tumor suppressor genes led to MSCs transformation $[54,56]$. The presence of lineage-specific genes at the mRNA level confirmed their physiological ability to differentiate into adipogenic, chondrogenic and osteogenic developmental lines. Higher expression of osteogenic-specific line genes (BGLAP, RUNX) probably indicates an ability to be prone towards osteogenesis. The lack of expression of $A D I P O Q$ and COL2A1 in undifferentiated MSCs was confirmed by other groups and can explained by the fact that these genes belong to genes expressed on more advanced stages of adipogenesis or chondrogenesis [57-61].

MSCs produce a wide range of cytokines, growth factors and chemokines. Due to secretory factors and direct cell-tocell contact, MSCs exhibit their immunomodulatory activity [62-65]. IL-6 is important in the initial phase of the humoral immune response [66], together with TGF- $\beta$ is involved part in balanced pro-inflammatory/anti-inflammatory reactions, directly inhibits Th17 response and stimulates the Treg population [66-71]. From the one side, presence of IL-6 with another pro-inflammatory cytokines promotes the induction of acute phase reaction, on the other it plays anti-inflammatory role, controlling the level of pro-inflammatory cytokines [68, $72,73]$. With this manuscript we join the others who proved, that MSCs secrete IL-6 at relatively high levels, which is suggested to be one of the key elements of MSCs immunomodulatory effects [74-78]. In our study, a high IL-6 level was presented in all cells, with the highest level was observed in $\mathrm{p} 8$ for PRV-MSCs.

The second important immunomodulatory factor is TGF- $\beta$, which was secreted by all analyzed MSCs populations. This growth factor is a key element for multiple vital functions of the cells including biological processes such as angiogenesis, immune response or endothelial-mesenchymal transition (EMT) [79-81]. As an immunomodulatory factor, TGF- $\beta 1$ shows the potential to inhibit the proliferation of Tcells, B-cells, NK cells and other immune cells $[63,76,80$, $81]$. TGF- $\beta 1$ is able to stimulate and increase the Treg population $[81,82]$. Interestingly, TGF- $\beta$ participates in activation and recruitment of MSCs in tissue repair processes in cooperation with MCP-1, increasing MSCs migration to the injured area [83]. According to our analysis, stable level of TGF- $\beta 1$ were presented by cells from passages 3 and 8 , and suggests that stable and high level of TGF- $\beta 1$ in cells is a second key element of immunomodulatory properties of MSCs. TGF- $\beta 2$ together with TGF- $\beta 1$ regulate crucial vital functions such as cell proliferation and differentiation. All studied cells on P3 showed relatively low levels of TGF- $\beta 2$ due to the fact that this protein probably plays a minor role in the regulation of immunomodulation and other important cellular processes.

Our study confirmed the presence of MCP-1 in our investigated cells. In recent studies, the presence of MCP-1 (CCL-2) secreted by MSCs might be associated with immunomodulatory potential of these cells $[84,85]$. The influence of MCP-1 on immunomodulation, including inhibition of immunoglobulin production by plasma cells and also influence on macrophage function, was emphasized [86, 87]. Additionally, MCP-1 able to promote MSCs cellular migration process $[85,88]$.

IL-8 produced by mesenchymal cells, belongs to proangiogenic, pro-migratory chemokine and participates in neutrophil recruitment [89]. The knockdown of IL-8 contributes to premature MSCs senescence, confirming that IL- 8 is very important for MSCs functionality. The IL-8/CXCR2 signaling pathway is most probably essential for young cells to promote their growth and activity, while at the same time improving senescence in old cells is probably related to increased IL-8 levels in our P8 cells [90].

We did not detect IFN- $\gamma$, FGF-2, GM-CSF, IL-17A, IL-2, MIP- $1 \alpha$, TGF- $\beta 3$ in any MSC supernatant and this observation is in agreement with previous published results [91, 92]. In the case of G-CSF, IFN $\alpha$, PDGF AA our analysis shows their low concentrations in supernatants, which stays in line with other reports. Nevertheless, the presence of EGF, IL-1 $\beta$, $\mathrm{TNF} \alpha$ was confirmed in our study at low concentrations in supernatants, while IL-12, MIP-1 $\beta$, IL-3, IL-4, IL-5, IL-10 were not noticed in supernatant, suggesting a difference in secretome composition [91, 92]. The differences between our results and results showed by others, could be explained probably by the differences in UC donor's criteria, individual variation, health condition and age of each donor or may be sex of child, as previously mentioned [93-96].

WJ-MSC were used in many plethora of application. In neurology, WJ-MSCs are administered to patients with amyotrophic lateral sclerosis, multiple sclerosis, spinal cord injury as well acute and chronic stroke [88, 97, 98]. Research is also being conducted on WJ-MSC in neurological diseases in young patients with cerebral palsy, autism, traumatic brain damage and hypoxic-ischemic encephalopathy. WJ-MSCs were also used in hematology (aplastic anemia, graft-versus host disease (GVHD)), cardiology (chronic coronary disease, heart failure), immunology (systemic lupus erythematosus), musculoskeletal diseases (Duchene and Becker disease) and others (including rare diseases) [99-103] These clinical trials do not exceed phase II. Most of them have demonstrated safety in clinical use, but minority treated efficacy as a main endpoint. There were different doses and different routes of administration (including intravenous, local or intramuscular) [104]. Although being intensively 
investigated, the mechanism of action and the efficacy of MSCbased therapies remain the principal issue for MSCs therapy approval in many cases.

In conclusion, our data suggests that WJ-MSCs are definitely the most promising and stable source of homogeneous MSCs among UC tissues, and that the isolation of MSCs from UC may be limited to this area, which would potentially be beneficial in cell-based therapy. One should mention that the appropriate awareness should be applied during WJ-MSC preparation for clinical application to avoid contamination from other UC compartments as this could influence the quantities and qualities of obtained Advanced Therapy Medicinal Products.

Authors' Contributions Conceptualization, Ekaterina Semenova, Eugeniusz K Machaj, Tomasz J Kolanowski and Tomasz Oldak; Formal analysis, Ekaterina Semenova, Mariusz P Grudniak, Katarzyna Bocian and Natalia Rozwadowska; Funding acquisition, Dariusz Boruczkowski and Tomasz Oldak; Investigation, Ekaterina Semenova, Marzena Trochonowicz, Igor M Stepaniec and Magdalena Murzyn; Project administration, Tomasz Oldak; Resources, Karolina Zagorska; Supervision, Tomasz Oldak and Natalia Rozwadowska; Validation, Magdalena Chroscinska-Krawczyk; Visualization, Natalia Rozwadowska; Writing - original draft, Ekaterina Semenova, Mariusz P Grudniak and Katarzyna Bocian; Writing - review \& editing, Tomasz J Kolanowski, Tomasz Oldak and Natalia Rozwadowska.

Funding This work was supported by a grant Strategmed2/269807/14/ NCBR/2015 from The National Centre for Research and Development, Poland.

\section{Data Availability N/A}

Code Availability N/A

\section{Declarations}

Ethics Approval Ethics approval (include appropriate approvals or waivers) according to a decision approved by the Committee of the Ministry of Health in Poland, No: SZTR.4061.9.2019.MN

\section{Consent to Participate N/A}

\section{Consent for Publication N/A}

Conflicts of Interest/Competing Interests ES, MPG, EKM, KB, MT, IMS, MM, KEZ, DB, TJK are current employees or have been employed by Polish Stem Cell Bank S.A. during their contribution to the manuscript, TO is a member of the board of PSCB S.A. NR has ongoing collaboration with PSCB S.A. MC-K is a current employees by Clinic of Paediatric Neurology, III Faculty of Paediatrics, Medical University of Lublin, NR has ongoing collaboration with PSCB S.A.

Open Access This article is licensed under a Creative Commons Attribution 4.0 International License, which permits use, sharing, adaptation, distribution and reproduction in any medium or format, as long as you give appropriate credit to the original author(s) and the source, provide a link to the Creative Commons licence, and indicate if changes were made. The images or other third party material in this article are included in the article's Creative Commons licence, unless indicated otherwise in a credit line to the material. If material is not included in the article's Creative Commons licence and your intended use is not permitted by statutory regulation or exceeds the permitted use, you will need to obtain permission directly from the copyright holder. To view a copy of this licence, visit http://creativecommons.org/licenses/by/4.0/.

\section{References}

1. Baksh, D., Yao, R., \& Tuan, R. S. (2007). Comparison of proliferative and multilineage differentiation potential of human Mesenchymal stem cells derived from umbilical cord and bone marrow. Stem Cells, 25, 1384-1392.

2. Stolzing, A., Jones, E., McGonagle, D., \& Scutt, A. (2008). Agerelated changes in human bone marrow-derived mesenchymal stem cells: Consequences for cell therapies. Mechanisms of Ageing and Development, 129, 163-173.

3. Cheng, H.-Y., Ghetu, N., Wallace, C. G., et al. (2014). The impact of Mesenchymal stem cell source on proliferation, differentiation, immunomodulation and therapeutic efficacy. J Stem Cell Res Ther, 4, 237.

4. Pittenger, M. F., Discher, D. E., Péault, B. M., et al. (2019). Mesenchymal stem cell perspective: cell biology to clinical progress. npj Regenerative Medicine, 4, 22.

5. Dominici, M., le Blanc, K., Mueller, I., Slaper-Cortenbach, I., Marini, F., Krause, D., Deans, R., Keating, A., Prockop Dj, \& Horwitz, E. (2006). Minimal criteria for defining multipotent mesenchymal stromal cells. The International Society for Cellular Therapy position statement. Cytotherapy, 8, 315-317.

6. Krampera, M., Galipeau, J., Shi, Y., Tarte, K., Sensebe, L., \& MSC Committee of the International Society for Cellular Therapy (ISCT). (2013). Immunological characterization of multipotent mesenchymal stromal cells-the international society for cellular therapy (ISCT) working proposal. Cytotherapy, 15, 1054-1061.

7. Weiss, M. L., \& Troyer, D. L. (2006). Stem cells in the umbilical cord. Stem Cell Reviews, 2, 155-162.

8. Semenova, E., Mrowiec, Z. R., Machaj, E. K., et al. (2017). Isolation and characteristics of Mesenchymal stromal cells from different parts of placenta. J Stem Cell Res Ther, 7, 376.

9. Semenova, E., Chroscinska-Krawczyk, M., Grudniak, M. P., et al. (2018). Clinical application of AD-MSCs - A review. Journal of Pre-Clinical and Clinical Research, 12, 100-105.

10. Marquez, M. P., Alencastro, F., Madrigal, A., Jimenez, J. L., Blanco, G., Gureghian, A., Keagy, L., Lee, C., Liu, R., Tan, L., Deignan, K., Armstrong, B., \& Zhao, Y. (2017). The role of cellular proliferation in Adipogenic differentiation of human adipose tissue-derived Mesenchymal stem cells. Stem Cells and Development, 26, 1578-1595.

11. Carrington, L. M., \& Boulton, M. (2005). Hepatocyte growth factor and keratinocyte growth factor regulation of epithelial and stromal corneal wound healing. Journal of Cataract and Refractive Surgery, 31, 412-423.

12. Karantalis, V., Balkan, W., Schulman, I. H., et al. (2012). Cellbased therapy for prevention and reversal of myocardial remodeling. American Journal of Physiology - Heart and Circulatory Physiology, 303, 256-270.

13. Hare, J. M., Fishman, J. E., Gerstenblith, G., DiFede Velazquez, D. L., Zambrano, J. P., Suncion, V. Y., Tracy, M., Ghersin, E., Johnston, P. V., Brinker, J. A., Breton, E., Davis-Sproul, J., Byrnes, J., George, R., Lardo, A., Schulman, I. H., Mendizabal, A. M., Lowery, M. H., Rouy, D., Altman, P., Wong Po Foo, C., 
Ruiz, P., Amador, A., da Silva, J., McNiece, I. K., \& Heldman, A. W. (2012). Comparison of allogeneic vs autologous bone marrowderived mesenchymal stem cells delivered by transendocardial injection in patients with ischemic cardiomyopathy: The POSEIDON randomized trial. JAMA : The Journal of the American Medical Association, 308, 2369-2379.

14. Usunier, B., Benderitter, M., Tamarat, R., \& Chapel, A. (2014). Management of Fibrosis: The Mesenchymal stromal cells breakthrough. Stem Cells International, 2014, 340257.

15. Prockop, D. J., \& Oh, J. Y. (2012). Mesenchymal stem/stromal cells (MSCs): Role as guardians of inflammation. Molecular Therapy, 20, 14-20.

16. Uccelli, A., Pistoia, V., \& Moretta, L. (2007). Mesenchymal stem cells: A new strategy for immunosuppression? Trends in Immunology, 28, 219-226.

17. Zhang, J., Li, Y., Lu, M., Cui, Y., Chen, J., Noffsinger, L., Elias, S. B., \& Chopp, M. (2006). Bone marrow stromal cells reduce axonal loss in experimental autoimmune encephalomyelitis mice. Journal of Neuroscience Research, 84, 587-595.

18. Gordon, D., Pavlovska, G., Uney, J. B., Wraith, D. C., \& Scolding, N. J. (2010). Human mesenchymal stem cells infiltrate the spinal cord, reduce demyelination, and localize to white matter lesions in experimental autoimmune encephalomyelitis. Journal of Neuropathology and Experimental Neurology, 69, 1087-1095.

19. Kemp, K., Hares, K., Mallam, E., Heesom, K. J., Scolding, N., \& Wilkins, A. (2010). Mesenchymal stem cell-secreted superoxide dismutase promotes cerebellar neuronal survival. Journal of Neurochemistry, 114, 1569-1580.

20. Wang, F., Yasuhara, T., Shingo, T., Kameda, M., Tajiri, N., Yuan, W., Kondo, A., Kadota, T., Baba, T., Tayra, J., Kikuchi, Y., Miyoshi, Y., \& Date, I. (2010). Intravenous administration of mesenchymal stem cells exerts therapeutic effects on parkinsonian model of rats: Focusing on neuroprotective effects of stromal cellderived factor-1 $\alpha$. BMC Neuroscience, 11, 52 .

21. Moloney, T. C., Rooney, G. E., Barry, F. P., Howard, L., \& Dowd, E. (2010). Potential of rat bone marrow-derived mesenchymal stem cells as vehicles for delivery of neurotrophins to the Parkinsonian rat brain. Brain Research, 1359, 33-43.

22. Ma, T., Gong, K., Ao, Q., et al. (2013). Intracerebral transplantation of adipose-derived mesenchymal stem cells alternatively activates microglia and ameliorates neuropathological deficits in Alzheimer's disease mice. Cell Transplantation, 22.

23. Shin, J. Y., Park, H. J., Kim, H. N., Oh, S. H., Bae, J. S., Ha, H. J., \& Lee, P. H. (2014). Mesenchymal stem cells enhance autophagy and increase $\beta$-amyloid clearance in Alzheimer disease models. Autophagy, 10, 32-44.

24. Sadlik, B., Jaroslawski, G., Puszkarz, M., Blasiak, A., Oldak, T., Gladysz, D., \& Whyte, G. P. (2018). Cartilage repair in the knee using umbilical cord Wharton's jelly-derived Mesenchymal stem cells embedded onto collagen scaffolding and implanted under dry arthroscopy. Arthroscopy Techniques, 7, e57-e63.

25. Sadlik, B., Jaroslawski, G., Gladysz, D., et al. (2017). Knee cartilage regeneration with umbilical cord mesenchymal stem cells embedded in collagen scaffold using dry arthroscopy technique. Advances in Experimental Medicine and Biology, 1020, 113-122.

26. Conconi, M. T., di Liddo, R., Tommasini, M., et al. (2011). Phenotype and differentiation potential of stromal populations obtained from various zones of human umbilical cord: An overview. The Open Tissue Engineering and Regenerative Medicine Journal, 4, 6-20.

27. Sarugaser, R., Lickorish, D., Baksh, D., Hosseini, M. M., \& Davies, J. E. (2005). Human umbilical cord perivascular (HUCPV) cells: A source of Mesenchymal progenitors. Stem Cells, 23, 220-229.
28. Troyer, D. L., \& Weiss, M. L. (2008). Concise review: Wharton's jelly-derived cells are a primitive stromal cell population. Stem Cells, 26, 591-599.

29. Kita, K., Gauglitz, G. G., Phan, T. T., Herndon, D. N., \& Jeschke, M. G. (2010). Isolation and characterization of Mesenchymal stem cells from the sub-amniotic human umbilical cord lining membrane. Stem Cells and Development, 19, 491-501.

30. Redaelli, S., Bentivegna, A., Foudah, D., Miloso, M., Redondo, J., Riva, G., Baronchelli, S., Dalpra, L., \& Tredici, G. (2012). From cytogenomic to epigenomic profiles: Monitoring the biologic behavior of in vitro cultured human bone marrow mesenchymal stem cells. Stem Cell Research \& Therapy, 3(6), 47.

31. Alunno, A., Bistoni, O., Montanucci, P., Basta, G., Calafiore, R., \& Gerli, R. (2018). Umbilical cord mesenchymal stem cells for the treatment of autoimmune diseases: Beware of cell-to-cell contact. Annals of the Rheumatic Diseases, 77, e14.

32. Meng, M., Liu, Y., Wang, W., Wei, C., Liu, F., du, Z., Xie, Y., Tang, W., Hou, Z., \& Li, Q. (2018). Umbilical cord mesenchymal stem cell transplantation in the treatment of multiple sclerosis. American Journal of Translational Research, 10, 212-223.

33. Lim, I. J., \& Phan, T. T. (2014). Epithelial and mesenchymal stem cells from the umbilical cord lining membrane. Cell Transplantation, 23, 497-503.

34. Doan, C. C., Le, T. L., Hoang, N. S., et al. (2014). Differentiation of umbilical cord lining membrane-derived mesenchymal stem cells into endothelial-like cells. Iranian Biomedical Journal, 18, 67-75.

35. Xu, M., Zhang, B., Liu, Y., Zhang, J., Sheng, H., Shi, R., Liao, L., Liu, N., Hu, J., Wang, J., Ning, H., Liu, T., Zhang, Y., \& Chen, H. (2014). The immunologic and hematopoietic profiles of Mesenchymal stem cells derived from different sections of human umbilical cord. Acta Biochimica et Biophysica Sinica, 46(12), 1056-1065.

36. Subramanian, A., Fong, C. Y., Biswas, A., \& Bongso, A. (2015). Comparative characterization of cells from the various compartments of the human umbilical cord shows that the Wharton's jelly compartment provides the best source of clinically utilizable mesenchymal stem cells. PLoS One, 10(6), e 0127992.

37. Bongso, A., \& Fong, C. Y. (2013). The therapeutic potential, challenges and future clinical directions of stem cells from the Wharton's jelly of the human umbilical cord. Stem Cell Reviews and Reports, 9, 226-240.

38. Holmannová, D., Kolácková, M., Kondélková, K., et al. (2012). CD200/CD200R paired potent inhibitory molecules regulating immune and inflammatory responses; part I: CD200/CD200R structure, activation, and function. Acta medica (Hradec Králové) / Universitas Carolina. Facultas Medica Hradec Králové, 55, 12-17.

39. Pietilä, M., Lehtonen, S., Tuovinen, E., Lähteenmäki, K., Laitinen, S., Leskelä, H. V., Nätynki, A., Pesälä, J., Nordström, K., \& Lehenkari, P. (2012). CD200 positive human mesenchymal stem cells suppress TNF-alpha secretion from CD200 receptor positive macrophage-like cells. PLoS One, 7(2), e31671.

40. Najar, M., Raicevic, G., Jebbawi, F., de Bruyn, C., Meuleman, N., Bron, D., Toungouz, M., \& Lagneaux, L. (2012). Characterization and functionality of the CD200-CD200R system during mesenchymal stromal cell interactions with T-lymphocytes. Immunology Letters, 146, 50-56.

41. la Rocca, G., \& lo Iacono, M., Corsello, T., et al. (2013). Human Wharton's jelly Mesenchymal stem cells maintain the expression of key Immunomodulatory molecules when subjected to Osteogenic, Adipogenic and Chondrogenic differentiation in vitro: New perspectives for cellular therapy. Current Stem Cell Research \& Therapy, 8, 100-113.

42. Donders, R., Bogie, J., Ravanidis, S., et al. (2018). Human Wharton's jelly-derived stem cells display a distinct Immunomodulatory and Proregenerative transcriptional signature compared to bone marrow-derived stem cells. Stem Cells and Development, 27, 65-84. 
43. Bárcia, R. N., Santos, J. M., Filipe, M., et al. (2015). What makes umbilical cord tissue-derived Mesenchymal stromal cells superior immunomodulators when compared to bone marrow derived Mesenchymal stromal cells? https://doi.org/10.1155/2015/583984.

44. Varnum, M. M., Kiyota, T., Ingraham, K. L., Ikezu, S., \& Ikezu, T. (2015). The anti-inflammatory glycoprotein, CD200, restores neurogenesis and enhances amyloid phagocytosis in a mouse model of Alzheimer's disease. Neurobiology of Aging, 36, 2995-3007.

45. Yang, Y., Zhang, X.-j., Zhang, C., et al. (2018). Loss of neuronal CD200 contributed to microglial activation after acute cerebral ischemia in mice. Neuroscience Letters, 678, 48-54.

46. Sun, H., Li, A., Hou, T., Tao, X., Chen, M., Wu, C., Chen, S., Zhu, L., \& Liao, H. (2019). Neurogenesis promoted by the CD200/ CD200R signaling pathway following treadmill exercise enhances post-stroke functional recovery in rats. Brain, Behavior, and Immunity, 82, 354-371.

47. Li, Z., Ye, H., Cai, X., Sun, W., He, B., Yang, Z., \& Xu, P. (2019). Bone marrow-mesenchymal stem cells modulate microglial activation in the peri-infarct area in rats during the acute phase of stroke. Brain Research Bulletin, 153, 324-333.

48. Zhang, S., Wang, X. J., Tian, L. P., Pan, J., Lu, G. Q., Zhang, Y. J., Ding, J. Q., \& Chen, S. D. (2011). CD200-CD200R dysfunction exacerbates microglial activation and dopaminergic neurodegeneration in a rat model of Parkinson's disease. Journal of Neuroinflammation, 8, 154.

49. Liu, Y., Bando, Y., Vargas-Lowy, D., Elyaman, W., Khoury, S. J., Huang, T., Reif, K., \& Chitnis, T. (2010). CD200R1 agonist attenuates mechanisms of chronic disease in a murine model of multiple sclerosis. Journal of Neuroscience, 30, 2025-2038.

50. Gandarillas, A., \& Watt, F. M. (1997). C-Myc promotes differentiation of human epidermal stem cells. Genes and Development, 11, 2869-2882

51. Paula, A. C., Martins, T. M., Zonari, A., Frade, S. P. P. J., Angelo, P. C., Gomes, D. A., \& Goes, A. M. (2015). Human adipose tissuederived stem cells cultured in xeno-free culture condition enhance cMYC expression increasing proliferation but bypassing spontaneous cell transformation. Stem Cell Research \& Therapy, 6(1), 76.

52. Knoepfler, P. S. (2008). Why Myc? An unexpected ingredient in the stem cell cocktail. Cell Stem Cell, 2, 18-21.

53. Nair, R., Roden, D. L., Teo, W. S., McFarland, A., Junankar, S., Ye, S., Nguyen, A., Yang, J., Nikolic, I., Hui, M., Morey, A., Shah, J., Pfefferle, A. D., Usary, J., Selinger, C., Baker, L. A., Armstrong, N., Cowley, M. J., Naylor, M. J., Ormandy, C. J., Lakhani, S. R., Herschkowitz, J. I., Perou, C. M., Kaplan, W., O'Toole, S. A., \& Swarbrick, A. (2014). C-Myc and Her2 cooperate to drive a stem-like phenotype with poor prognosis in breast cancer. Oncogene, 33, 3992-4002.

54. Shimizu, T., Ishikawa, T., Sugihara, E., Kuninaka, S., Miyamoto, T., Mabuchi, Y., Matsuzaki, Y., Tsunoda, T., Miya, F., Morioka, H., Nakayama, R., Kobayashi, E., Toyama, Y., Kawai, A., Ichikawa, H., Hasegawa, T., Okada, S., Ito, T., Ikeda, Y., Suda, T., \& Saya, H. (2010). C-MYC overexpression with loss of Ink4a/ Arf transforms bone marrow stromal cells into osteosarcoma accompanied by loss of adipogenesis. Oncogene, 29, 5687-5699.

55. Melnik, S., Werth, N., Boeuf, S., Hahn, E. M., Gotterbarm, T., Anton, M., \& Richter, W. (2019). Impact of c-MYC expression on proliferation, differentiation, and risk of neoplastic transformation of human mesenchymal stromal cells. Stem Cell Research \& Therapy, 10, 73.

56. Wang, J.-Y., Wu, P.-K., Chen, P. C.-H., Lee, C. W., Chen, W. M., \& Hung, S. C. (2017). Generation of osteosarcomas from a combination of $\mathrm{Rb}$ silencing and c-Myc overexpression in human Mesenchymal stem cells. Stem Cells Translational Medicine, 6, 512-526.

57. Amable, P. R., Teixeira, M. V., Carias, R. B., Granjeiro, J. M., \& Borojevic, R. (2014). Gene expression and protein secretion during human mesenchymal cell differentiation into adipogenic cells. BMC Cell Biology, 15, 46.
58. Mohanty, N., Gulati, B. R., Kumar, R., Gera, S., Kumar, S., Kumar, P., \& Yadav, P. S. (2016). Phenotypical and functional characteristics of mesenchymal stem cells derived from equine umbilical cord blood. Cytotechnology, 68, 795-807.

59. Menssen, A., Häupl, T., Sittinger, M., Delorme, B., Charbord, P., \& Ringe, J. (2011). Differential gene expression profiling of human bone marrow-derived mesenchymal stem cells during adipogenic development. BMC Genomics, 12, 461.

60. Hu, E., Liang, P., \& Spiegelman, B. M. (1996). AdipoQ is a novel adipose-specific gene dysregulated in obesity. Journal of Biological Chemistry, 271, 10697-10703.

61. Zołocińska, A. (2018). The expression of marker genes during the differentiation of Mesenchymal stromal cells. Advances in clinical and experimental medicine : official organ Wroclaw Medical University, 27(5), 717-723.

62. Leuning, D. G., Beijer, N. R. M., du Fossé, N. A., Vermeulen, S., Lievers, E., van Kooten, C., Rabelink, T. J., \& Boer, J. . (2018). The cytokine secretion profile of mesenchymal stromal cells is determined by surface structure of the microenvironment. Scientific Reports, 8, 7716.

63. Di Nicola, M., Carlo-Stella, C., Magni, M., et al. (2002). Human bone marrow stromal cells suppress T-lymphocyte proliferation induced by cellular or nonspecific mitogenic stimuli. Blood, 99, 3838-3843.

64. Bochev, I., Elmadjian, G., Kyurkchiev, D., Tzvetanov, L., Altankova, I., Tivchev, P., \& Kyurkchiev, S. (2008). Mesenchymal stem cells from human bone marrow or adipose tissue differently modulate mitogen-stimulated B-cell immunoglobulin production in vitro. Cell Biology International, 32, 384-393.

65. di Ianni, M., del Papa, B., de Ioanni, M., Moretti, L., Bonifacio, E., Cecchini, D., Sportoletti, P., Falzetti, F., \& Tabilio, A. (2008). Mesenchymal cells recruit and regulate $\mathrm{T}$ regulatory cells. Experimental Hematology, 36, 309-318.

66. Kimura, A., \& Kishimoto, T. (2010). IL-6: Regulator of Treg/ Th17 balance. European Journal of Immunology, 40, 1830-1835.

67. Nakagawa, T., Tsuruoka, M., Ogura, H., Okuyama, Y., Arima, Y., Hirano, T., \& Murakami, M. (2010). IL-6 positively regulates Foxp3 $1 \mathrm{CD} 81 \mathrm{~T}$ cells in vivo. International Immunology, 22, 129-139.

68. Scheller, J., Chalaris, A., Schmidt-Arras, D., \& Rose-John, S. (2011). The pro- and anti-inflammatory properties of the cytokine interleukin-6. Biochimica et Biophysica Acta, Molecular Cell Research, 1813, 878-888.

69. Ivanova-Todorova, E., Bochev, I., Dimitrov, R., et al. (2012). Conditioned medium from adipose tissue-derived Mesenchymal stem cells induces CD4+FOXP3+ cells and increases IL-10 secretion. Journal of Biomedicine and Biotechnology, 2012, 295167.

70. Kyurkchiev, D., Ivanova-Todorova, E., Bochev, I., Mourdjeva, M., \& Kyurkchiev, S. (2013). Differences between adipose tissue- derived mesenchymal stem cells and bone marrow-derived mesenchymal stem cells as regulators of the immune response (pp 71-84). In In: Stem cells and Cancer stem cells, volume 10: Therapeutic applications in disease and injury. Netherlands: Springer.

71. Bernardo, M. E., \& Fibbe, W. E. (2013). Mesenchymal stromal cells: Sensors and switchers of inflammation. Cell Stem Cell, 13, 392-402.

72. Xing, Z., Gauldie, J., Cox, G., Baumann, H., Jordana, M., Lei, X. F., \& Achong, M. K. (1998). IL-6 is an antiinflammatory cytokine required for controlling local or systemic acute inflammatory responses. Journal of Clinical Investigation, 101, 311-320.

73. Tanaka, T., Narazaki, M., \& Kishimoto, T. (2014). Il-6 in inflammation, immunity, and disease. Cold Spring Harbor Perspectives in Biology, 6(10), a016295.

74. Park, C. W., Kim, K. S., Bae, S., Son, H. K., Myung, P. K., Hong, H. J., \& Kim, H. (2009). Cytokine secretion profiling of human mesenchymal stem cells by antibody array. International Journal of Stem Cells, 2, 59-68. 
75. Newman, R. E., Yoo, D., LeRoux, M. A., \& DanilkovitchMiagkova, A. (2009). Treatment of inflammatory diseases with mesenchymal stem cells. Inflammation \& Allergy Drug Targets, $8,110-123$.

76. Bouffi, C., Bony, C., Courties, G., Jorgensen, C., \& Noël, D. (2010). IL-6-dependent PGE2 secretion by mesenchymal stem cells inhibits local inflammation in experimental arthritis. PLoS One, 5(12), e14247.

77. Ben-Ami, E., Berrih-Aknin, S., \& Miller, A. (2011). Mesenchymal stem cells as an immunomodulatory therapeutic strategy for autoimmune diseases. Autoimmunity Reviews, 10, 410-415.

78. Kyurkchiev, D., Bochev, I., Ivanova-Todorova, E., Mourdjeva, M., Oreshkova, T., Belemezova, K., \& Kyurkchiev, S. (2014). Secretion of immunoregulatory cytokines by mesenchymal stem cells. World J Stem Cells, 6, 552-570.

79. Li, M. O., Wan, Y. Y., Sanjabi, S., Robertson, A. K. L., \& Flavell, R. A. (2006). Transforming growth factor-beta regulation of immune responses. Annual Review of Immunology, 24, 99-146.

80. Yoshimura, A., \& Muto, G. (2011). TGF- $\beta$ function in immune suppression. In: Current topics in microbiology and immunology. Current Topics in Microbiology and Immunology, 350, 127-147.

81. Groh, M. E., Maitra, B., Szekely, E., \& Koc,, O. N. (2005). Human mesenchymal stem cells require monocyte-mediated activation to suppress alloreactive T cells. Experimental Hematology, 33, 928-934.

82. English, K., Ryan, J. M., Tobin, L., Murphy, M. J., Barry, F. P., \& Mahon, B. P. (2009). Cell contact, prostaglandin E2 and transforming growth factor beta 1 play non-redundant roles in human mesenchymal stem cell induction of CD4+ CD25Highforkhead box P3+ regulatory $\mathrm{T}$ cells. Clinical and Experimental Immunology, 156, 149-160.

83. Xu, X., Zheng, L., Yuan, Q., Zhen, G., Crane, J. L., Zhou, X., \& Cao, X. (2018). Transforming growth factor- $\beta$ in stem cells and tissue homeostasis. Bone Research, 6, 2.

84. Akiyama, K., Chen, C., Wang, D., Xu, X., Qu, C., Yamaza, T., Cai, T., Chen, W. J., Sun, L., \& Shi, S. (2012). Mesenchymalstem-cell-induced immunoregulation involves FAS-ligand-/FASmediated T cell apoptosis. Cell Stem Cell, 10, 544-555.

85. Boomsma, R. A., \& Geenen, D. L. (2012). Mesenchymal stem cells secrete multiple cytokines that promote angiogenesis and have contrasting effects on chemotaxis and apoptosis. PLoS One, 7, e35685.

86. Rafei, M., Hsieh, J., Fortier, S., Li, M. Y., Yuan, S., Birman, E., Forner, K., Boivin, M. N., Doody, K., Tremblay, M., Annabi, B., \& Galipeau, J. (2008). Mesenchymal stromal cell derived CCL2 suppresses plasma cell immunoglobulin production via STAT3 inactivation and PAX5 induction. Blood, 112, 4991-4998.

87. Giri, J., Das, R., Nylen, E., et al. (2020). CCL2 and CXCL12 derived from Mesenchymal stromal cells cooperatively polarize IL-10+ tissue macrophages to mitigate gut injury. Cell Reports, 30(6), 1923-1934.e4.

88. Nishida, F., Zappa Villar, M. F., Zanuzzi, C. N., Sisti, M. S., Camiña, A. E., Reggiani, P. C., \& Portiansky, E. L. (2020). Intracerebroventricular delivery of human umbilical cord Mesenchymal stem cells as a promising therapy for repairing the spinal cord injury induced by Kainic acid. Stem Cell Reviews and Reports, 16, 167-180.

89. Waugh, D. J., \& Wilson, C. (2008). The interleukin-8 pathway in cancer. Clinical Cancer Research, 14(21), 6735-6741.

90. Li, J. J., Ma, F. X., Wang, Y. W., Chen, F., Lu, S. H., Chi, Y., du, W. J., Song, B. Q., Hu, L. D., Chen, H., \& Han, Z. C. (2017). Knockdown of IL-8 provoked premature senescence of placentaderived mesenchymal stem cells. Stem Cells and Development, 26, 912-931.

91. Amable, P. R., Teixeira, M. V., Carias, R. B., et al. (2014). Protein synthesis and secretion in human mesenchymal cells derived from bone marrow, adipose tissue and Wharton's jelly. Stem Cell Research \& Therapy, 5(2), 53.

92. Kalamegam, G., Sait, K., Anfinan, N., Kadam, R., Ahmed, F., Rasool, M., Naseer, M. I., Pushparaj, P. N., \& al-Qahtani, M. (2019). Cytokines secreted by human Wharton's jelly stem cells inhibit the proliferation of ovarian cancer (OVCAR3) cells in vitro. Oncology Letters, 17(5), 4521-4531.

93. Paladino, F. V., Peixoto-Cruz, J. S., Santacruz-Perez, C., \& Goldberg, A. C. (2016). Comparison between isolation protocols highlights intrinsic variability of human umbilical cord mesenchymal cells. Cell and Tissue Banking, 17, 123-136.

94. Swamynathan, P., Venugopal, P., Kannan, S., Thej, C., Kolkundar, U., Bhagwat, S., Ta, M., Majumdar, A., \& Balasubramanian, S. (2014). Are serum-free and xeno-free culture conditions ideal for large scale clinical grade expansion of Wharton's jelly derived mesenchymal stem cells? A comparative study. Stem Cell Research \& Therapy, 5(4), 88.

95. Mori, Y., Ohshimo, J., Shimazu, T., He, H., Takahashi, A., Yamamoto, Y., Tsunoda, H., Tojo, A., \& Nagamura-Inoue, T. (2015). Improved explant method to isolate umbilical cordderived mesenchymal stem cells and their immunosuppressive properties. Tissue Engineering - Part C: Methods, 21, 367-372.

96. Badraiq, H., Devito, L., \& Ilic, D. (2015). Isolation and expansion of mesenchymal stromal/stem cells from umbilical cord under chemically defined conditions. Methods in Molecular Biology, 1283, 65-71.

97. Barczewska, M., Maksymowicz, S., Zdolińska-Malinowska, I., Siwek, T., \& Grudniak, M. (2020). Umbilical cord Mesenchymal stem cells in amyotrophic lateral sclerosis: An original study. Stem Cell Reviews and Reports, 16, 922-932.

98. Dehghani, L., Hashemi, S. M., Saadatnia, M., Zali, A., OraeeYazdani, S., Heidari Keshel, S., Khojasteh, A., \& Soleimani, M. (2020). Stem cell-derived Exosomes as treatment for stroke: A systematic review. Stem Cell Reviews and Reports. https://doi. org/10.1007/s12015-020-10024-7.

99. Soder, R. P., Dawn, B., Weiss, M. L., Dunavin, N., Weir, S., Mitchell, J., Li, M., Shune, L., Singh, A. K., Ganguly, S., Morrison, M., Abdelhakim, H., Godwin, A. K., Abhyankar, S., \& McGuirk, J. (2020). A phase I study to evaluate two doses of Wharton's jelly-derived Mesenchymal stromal cells for the treatment of De novo high-risk or steroid-refractory acute graft versus host disease. Stem Cell Reviews and Reports, 16, 979-991.

100. Adami, R., \& Bottai, D. (2019). Spinal muscular atrophy modeling and treatment advances by induced pluripotent stem cells studies. Stem Cell Reviews and Reports, 15, 795-813.

101. Karamini, A., Bakopoulou, A., Andreadis, D., Gkiouras, K., \& Kritis, A. (2020). Therapeutic potential of Mesenchymal stromal stem cells in rheumatoid arthritis: A systematic review of in vivo studies. Stem Cell Reviews and Reports, 16, 276-287.

102. Hénon, P. (2020). Key success factors for regenerative medicine in acquired heart diseases. Stem Cell Reviews and Reports, 16, 441-458.

103. López, E., Blázquez, R., Marinaro, F., Álvarez, V., Blanco, V., Báez, C., González, I., Abad, A., Moreno, B., Sánchez-Margallo, F. M., Crisóstomo, V., \& Casado, J. G. (2020). The Intrapericardial delivery of extracellular vesicles from Cardiosphere-derived cells stimulates M2 polarization during the acute phase of porcine myocardial infarction. Stem Cell Reviews and Reports, 16, 612-625.

104. Can, A., Celikkan, F. T., \& Cinar, O. (2017). Umbilical cord mesenchymal stromal cell transplantations: A systemic analysis of clinical trials. Cytotherapy, 19, 1351-1382.

Publisher's Note Springer Nature remains neutral with regard to jurisdictional claims in published maps and institutional affiliations. 